\title{
Financial Development and Income Inequality Relationship: Analyzing Financial Kuznets Curve with ARDL Boundary Test in Turkey
}

\author{
Seyma Yilmaz Kuscuoglu (Corresponding author) \\ Kutahya Dumlupinar University, Institute of Graduate Education, \\ Department of Economy, Kutahya, Turkey \\ E-mail: seyma.yilmaz6@ogr.dpu.edu.tr \\ Macide Cicek \\ Kutahya Dumlupinar University, Faculty of Economics and Administrative Sciences \\ Department of Economy, Kutahya, Turkey \\ E-mail: macide.cicek@dpu.edu.tr
}

\begin{abstract}
In this study, the relationship between the financial development and the income inequality in Turkey is investigated by testing the validity of Financial Kuznets Curve Hypothesis. To examine this relationship for the period of 1987-2017, the variables of the public final consumption expenditures, the modern sector share, the inflation and the human capitalare also added to the model setted as control variables, and the long-term relationships among the variables are analyzed by using the ARDL (The Autoregressive Distributed Lag) Boundary Test approach. Empirical evidence refers to the validity of the Financial Kuznets Curve Hypothesis in Turkey, in other words, there is an inverse-U shaped relationship between the financial development and the income inequality. Accordingly, while the financial development raises the inequality in income distribution to a certain threshold level, it reduces the inequality after this threshold level in Turkey. Moreover, in the long run increases in the modern sector share, the public final consumption expenditures and in the trade openness help to reducing income inequality but increases in the inflation and in the human capital make worse income inequality.
\end{abstract}

Keywords: Financial Development, Income Inequality, Financial Kuznets Curve, ARDL Boundary Test.

DOI: $10.7176 / \mathrm{JSTR} / 7-01-07$

\section{Finansal Gelişme ve Gelir Eşitsizliği İlişkisi: Türkiye’de Finansal Kuznets Eğrisinin ARDL Sınır Testi İle Analizi}

\begin{abstract}
Özet
Bu çalışmada Türkiye'de finansal gelişme ve gelir eşitsizliği arasındaki ilişki Finansal Kuznets Eğrisi Hipotezinin geçerliliği test edilerek araştırılmıştır. Çalışmada, 1987-2017 döneminde söz konusu ilişkinin incelenmesi için oluşturulan modele, kontrol değişkeni olarak kamu nihai tüketim harcamaları, modern sektör, enflasyon ve beşeri sermaye değişkenleri de eklenmiş ve değişkenler arasındaki uzun dönemli ilişkiler ARDL (The Autoregressive Distributed Lag) Sınır Testi yaklaşımı kullanılarak analiz edilmiştir. Ampirik bulgular, Türkiye’de Finansal Kuznets Eğrisi Hipotezinin geçerli olduğunu, başka bir deyişle, Türkiye'de finansal gelişme ve gelir eşitsizliği arasında ters-U şeklinde bir ilişsi bulunduğunu göstermektedir. Buna göre, Türkiye'de finansal gelişme belirli bir eşik düzeye kadar gelir dağılımında eşitsizliği arttırırken, bu eşik düzeyden sonra eşitsizlik azalmaktadır. Ayrıca uzun dönemde modern sektör payı, kamu nihai tüketim harcamaları ve ticari açıklıktaki artışlar gelir eşitsizliğinin azalmasına yardımcı olmasına rağmen, enflasyon ve beşeri sermayede meydana gelen artışlar gelir eşitsizliğini arttırmaktadır.
\end{abstract}

Anahtar Kelimeler: Finansal Gelişme, Gelir Eşitsizliği, Finansal Kuznets Eğrisi, ARDL Sınır Testi.

79 | P a g e

www.iiste.org 


\section{Giriş}

İyi işleyen bir finansal sistem fiziksel sermaye birikimini teşvik etme, ekonomik etkinliği iyileştirme ve dolayısıyla uzun vadeli büyümeyi teşvik etme potansiyeline sahiptir (Levine, Loayza, \& Beck, 2000; Levine, 2003). Finansal sistemin bu özelliklerinin yanı sıra, gelirin nasıl dağılacağı üzerinde belirleyici bir etkisi olup olmadığı da uzun yıllar boyunca iktisatçılar ve politika yapıcalar tarafindan üzerinde fikir birliğine varılamamış bir soru olmaya devam etmiştir. Bazı iktisatçılar finansal gelişmenin düşük gelirliler lehine gelir eşitsizliğini azaltacağını ileri sürerken, bazıları ise finansal gelişmeden asıl fayda sağlayanların zengin ve politik bağlantılara sahip kişiler olacağını ileri sürmüsşür.

Finansal gelişmenin düşük gelirliler için fayda sağlayacağı düşüncesiyle tutarlı olarak ortaya çıkan teorik modellere göre, finansal piyasaların gelişimi ya da bu piyasada ortaya çıkan aksaklıklar özellikle teminat ve kredi geçmişi olmayan düşük gelirli bireyleri etkilemektedir. Çünkü finansal piyasalarda asimetrik bilgi ve ters seçim, sözleşme maliyetleri, bilgi ve işlem maliyetlerinin varlı̆̆ gibi piyasa kusurlarının bulunması, eğitimlerini ya da yüksek getirili yatırım projelerini finanse edecek kaynaklara sahip olmayan düşük gelirli bireylerin fon bulmalarını zorlaştırmaktadır. Kredi almak için teminata ya da siyasi bağlantılara sahip olmayan düşük gelirli bireylerin fon bulma konusunda yaşadıkları zorluklar, kaynakların etkin dağılımını azaltarak gelir eşitsizliğini arttırmaktadır. Böyle bir ortamda finansal piyasalarda yaşanan bir gelişme, kaynak dağılımında etkinliğini arttırarak yoksulların kredi kısıtlamalarını azaltacaktır. Böylece düşük gelirli bireyler kendileri veya çocuklarının eğitimi için gerekli fona ulaşabilecektir. Sonuç olarak yaptıkları eğitim harcaması ile beşeri sermayelerini arttıran ya da yeni bir iş kurmak için firsatı olan düşük gelirliler lehine gelir eşitsizliği azalacaktır (Thornton \& Di Tommaso, 2020: 1; Batuo, Guidi, \& Mlambo, 2010: 3; Clarke, Xu, \& Zou, 2006: 579; Levine, 2004).

Finansal sistemin gelişmesinden asıl fayda sağlayanların zengin ve politik bağlantıları olanlar olduğunu ileri süren görüsse göre ise, finansal hizmetlere (özellikle kredilere) erişim özellikle ekonomik kalkınmanın ilk aşamalarında varlıklı olmak ve kurumlarla bağlantılı olmakla ilişkilidir (Levine, 2004: 37). Finansal piyasalar ters seçim ve ahlaki tehlike sorunları ile dolu olduğundan, borçluların borç almaları için teminat gerekmektedir. Bu nedenle, teminata sahip olmayan düşük gelirli hane halkı, finansal piyasalar iyi gelişmiş olsa bile borç bulmakta zorlanmaktadır. Oysa, teminat olarak kullanabilecekleri bir servete sahip olan zenginler, finansal araçlara erişimleri kolay olduğundan, sektördeki gelişimden de fayda sağlayabilmektedirler (Clarke vd., 2006: 578). Bu koşullar altında daha büyük finansal gelişme sadece belirli bir azınlığa daha fazla sermaye aktaracaktır. Düşük gelirlilerin teminat ve bağlantı eksikliklerinden dolayı kredilere eşit erişimleri olmadığından, finansal gelişim gelir dağılımını onların aleyhine daha da kötüleştirecektir (Batuo vd., 2010: 3).

Finansal gelişme ve gelir eşitsizliği ilişkisine dair farklı görüşler sunan teorik literatürün yanı sıra, ampirik literatürde de bu ilişkiye odaklanan çalışmalar çelişkili tahminler sunmaktadır. Bu nedenle, Türkiye'de finansal gelişme ve gelir eşitsizliğini inceleyen sınırlı sayıda çalışmadan elde edilen ampirik kanıtlar da fikir birliğine ulaşılmasının önüne geçmektedir. Bu bağlamda, bu çalışmada literatüre katkı sağlamak amacı ile Türkiye'de 1987-2017 dönemi için finansal gelişme ve gelir eşitsizliği ilişsisi Finansal Kuznets Eğrisi Hipotezinin geçerliliği test edilerek araştırılmıştır. Çalışmada finansal gelişme düzeyi, finansal kurumların ve finansal piyasaların derinlik, erişim ve verimlilik boyutlarını birlikte ele alan ve Svirydzenka (2016) tarafindan geliştirilen finansal gelişme endeksi kullanılmıştır. Bu endeksin kullanımı çalışmamızı, Türkiye'de finansal gelişimi özel sektöre verilen banka kredilerinin GSYIH'ya oranı ve/veya geniş para arzının GSYIH'ya oranı gibi yalnızca bankacılık sektörünün gelişimini içeren ya da şirketlerin piyasa değerleri toplamının GSYİH'ya oranı gibi yalnızca sermaye piyasasının gelişimini içeren değişkenlerle ölçen diğer çalışmalardan ayırmaktadır.

Çalışmanın akışı şu şekildedir: İkinci bölümde, finansal gelişmenin ekonomik büyüme ve gelir eşitsizliği ile teorik ilişkisi incelenmiş, üçüncü bölümde konuya ilişkin ampirik literatür verilmiştir. Dördüncü bölümde çalş̧manın temel sorusunu test etmek için oluşturulan model ve kullanılan veri seti tanımlanmış ve beşinci bölümde ampirik bulgular sunulmuş ve yorumlanmıştır. Çalışmanın sonuç bölümünde ise, ulaşılan ampirik bulgular ışığında politika önerilerinde bulunulmuştur.

\section{Finansal Gelişme ve Gelir Dağılımı İlişsisinin Teorik Çerçevesi}

Finansal gelişmenin makro ekonomik değişkenler üzerindeki etkisinin incelenmesi ilk olarak finansal gelişmenin ekonomik büyüme üzerindeki etkisini inceleyen Goldsmith (1969) ile başlamıştır. Goldsmith (1969) ekonomik gelişmenin finansal sistemin gelişmesine ve iyileşmesine yol açtı̆̆gnı ileri sürmüştür (Guru \& Yadav, 2019: 117-118). Goldsmith (1969)'in çalışmasından sonra finansal gelişimin ekonomik büyüme ile bağlantısına ilişkin olarak çok sayıda çalışma yapılmış ve bu çalışmalar

$80 \mid \mathrm{P}$ a g e

www.iiste.org 
literatürde söz konusu değişkenler arasındaki bağlantılar için ileri sürdükleri kanallar açısından "yapısalcılar" ve "baskıcılar" olmak üzere ikiye ayrılmıştır. Yapısalcılar, sermaye oluşumunu arttırarak ekonominin büyümesine ve yoksulluğun azalmasina neden olan ana unsurun finansal değişkenlerin miktarı, bileşimi ve yapısı olduğunu ileri sürmektedir. Öncülüğünü McKinnon (1973) ve Shaw (1973)'ın yaptığı (daha sonra McKinnon-Shaw Hipotezi olarak adlandırılmıştır) finansal baskıcılar ise, finansal gelişimin reel nakit dengelerinin ekonomik büyümenin itici gücü olmasını sağlayan uygun bir getiri oranı oluşturduğunu iddia etmektedir. McKinnon-Shaw Hipotezinin temel prensibi, finansal gelişimin düşük olması durumunda düşük ya da negatif bir reel faiz oranı ortaya çıkacağına ve bu faiz oranının tasarruf ve yatırımlar için kredilendirilebilir fon arzını azaltarak ekonomik büyümeyi geriye çekeceğine dayanmaktadır. McKinnon-Shaw Hipotezinde finansal gelişme rekabeti artırarak faiz oranının artmasına neden olmakta, bu da tasarruf ve yatırımları arttırarak ekonomik büyümeyi hizlandırmaktadır (McKinnon, 1973; Shaw, 1973).

Levine (1997)'e göre finansal sistemler mal ve hizmet ticaretinin kolaylaştırılmasını, yatırımcıların riski çeşitlendirerek riskten korunmasını, sermaye birikimi ve teknolojik yeniliklere neden olarak ekonomik büyüme oranının artmasını sağlamaktadır. Buna göre, iyi gelişmiş bir finans piyasası ekonominin tasarruflarını karlı yatırımlara yönlendirmekte, bilgi maliyetini düşürerek sermayenin tahsisinde etkinliği arttırmakta ve aynı zamanda kurumsal yönetim maliyetini düşürmektedir. Ayrıca, gelişmiş finansal aracılar girişimcilere ödüller vererek teknolojik yeniliği arttırmakta ve böylece daha yüksek bir büyüme oranı için finansal kanalların etkinliğini arttırmaktadır (Levine, 1997). Levine (2004) finansal düzenlemelerin borçlanmayı kolaylaştırarak, beşeri sermaye birikimini de teşvik ettiğini ileri sürmüştür. Buna göre, eğer beşeri sermaye birikimi toplumsal düzeyde azalan getirilere tabi değilse, beşeri sermaye yaratmayı kolaylaştıran finansal düzenlemeler ekonomik büyümeyi hızlandırmaya da yardımcı olacaktır (Levine, 2004). King ve Levine (1993) ise finansal sistemlerin ekonomik büyümeyi etkilediği dört kanala vurgu yapmaktadır. Buna göre, daha gelişmiş bir finansal sistem; 1) daha kaliteli girişimcileri ve projeleri seçerek, 2) bu girişimciler için diş finansmana ulaşımı kolaylaştırarak, 3) inovasyon faaliyetlerinin risklerini çeşitlendirmek için üstün araçlar sağlayarak ve 4) belirsiz inovasyon işleri ile ilişkili potansiyel büyük karların daha doğru bir şekilde ortaya konmasını sağlayarak verimlilik artışı sağlamakta ve ekonomik büyümeyi uyarmaktadır (King \& Levine, 1993: 540).

Finansal gelişme ile gelir dağılımı arasındaki ilişkiyi inceleyen çalışmalar ise Greenwood ve Jovanovic (1990) ile başlamıştır. Kuznets (1955)'in ters-u şekilli Gelir Eşitsizliği ve Ekonomik Kalkınma Hipotezini temel alan Greenwood ve Jovanovic (1990) finansal gelişme ile gelir eşitsizliği arasındaki ilişkinin de aynı şekilde doğrusal olmadığını ileri sürmüştür. Finansal sektörler geliştikçe yüksek gelirlilere daha fazla borç vermeye devam etmekte, ancak diğer yandan teminat sağlayamayan yoksulları da ihmal etmektedir. Böylece finans sektörü gelişse bile yoksullar kentsel alanlara göç edememekte, eğitime yatırım yapamamakta veya yeni işler kuramamaktadır. Bunların yanı sıra eğer yüksek gelir dilimindeki ekonomik birimler yeni firmaların finansmana erişimlerini engelleme kabiliyetine sahipse, düşük gelirli yatırımcıların piyasaya giriş engelleri daha da artacak ve yoksulların ekonomik paylarını arttırma olanakları da azalacaktır. Böyle bir durumun varlığında, en azından finansal gelişimin belirli düzeyleri için finansal gelişme ve gelir eşitsizliği arasında pozitif bir ilişki olması beklenebilmektedir. Bu durum literatürde yaygın olarak "Eşitsizlik Arttırıcı Hipotez" olarak adlandırılmaktadır. Ancak diğer yandan, finansal sistem geliştikçe sermaye tahsisini geliştirecek ve büyümeyi arttıracaktır. Ekonomik büyüme arttıkça, daha fazla insan ekonomik açıdan finansal sisteme katılma imkânına sahip olacaktır. Böylece ekonomik gelişmenin erken aşamalarında finansal gelişimin gelir dağılımı etkisi olumsuz iken, belirli bir dönüş noktasından sonra olumludur. Bu yüzden Greenwood ve Jovanovic (1990) modeli, gelir eşitsizliği ve finansal sektör gelişimi arasındaki ilişkiyi gelir eşitsizliğini önce arttıran, sonra azaltan ve sonunda daha fazla birey finansal kurumlara katıldıkça sabitleyen ters-u şeklinde tahmin etmektedir (Greenwood \& Jovanovic, 1990). Bu durum literatürde "Finansal Gelişmenin Ters-U Hipotezi" ya da "Finansal Kuznets Eğrisi Hipotezi" olarak adlandırılmaktadır (Argun, 2016: 64).

Banerjee ve Newman (1993) ve Galor ve Zeira (1993)'ya gore asimetrik bilgi, ters seçim ve ahlaki riziko gibi sermaye piyasası kusurlarının varlığı ile beşeri ve fiziki sermayeye yapılan yatırımların bölünmezliği, gelir eşitsizliğini arttırmaktadır. Ayrıca bir ülkedeki ilk servet dağılımının yüksek eşitsizlik üzerine kurulu olması durumunda sermaye piyasası kusurlarının varlığı, uzun vadede gelir eşitsizliğinin devam edeceği anlamına bile gelebilmektedir. Bu modeller daha büyük sermaye piyasa aksaklıklarının varlığında, yani bölünmez yatırımları finanse etmek için ödünç verilebilir fonları almada daha yüksek engeller olduğunda, finansal gelişmenin gelir eşitsizliğini azaltacağını ileri

81 | $P$ a g e 
sürmektedir. Galor ve Zeira (1993), beşeri sermayeye bölünmez bir yatırım yapan bireylerin beceri yoğun bir sektörde çalışabildiği, kuşaklar arasında mirasları olan iki sektörlü bir model oluşturmuştur. Modelde sermaye piyasası kusurları göz önüne alındığında, sadece yatırım tutarından daha büyük mirasa sahip olanlar veya bu miktarı borç alabilen bireylerin bu yatırımı yapabileceği varsayılmaktadır. Galor ve Zeira (1993) bu varsayıma dayanarak, gelir eşitsizliğinin gelecek nesillere miras olarak bırakılacağını ileri sürmektedir. Onların modelinde sermaye piyasasında kusurlar olan ve başlangıçtaki servet dağ 1 lımı adil olmayan bir ekonomide gelir dağılımındaki bu eşitsizlik devam edecek ve böyle bir ekonomi başlangıçtaki servet dağılımı daha adil olan benzer bir ekonomiden daha yavaş büyüyecektir. Ancak başlangıç servet dağılımının adil olmadığı söz konusu ekonomide meydana gelen finansal gelişme, yoksullar lehine gelir eşitsizliğini azaltacaktır. Benzer şekilde, Banerjee ve Newman (1993) da teknolojisinin ikisi bölünmez yatırım gerektiren üç sektörlü bir model oluşturmuştur. Sermaye piyasası kusurları nedeniyle yalnızca yüksek gelire sahip olanlar bölünmez ve yüksek getirili teknolojileri çalşstırmak için yeterli borç alabilmektedir. Böylece sermaye piyasasında daha fazla kusura sahip olan ülkelerde gelir eşitsizliği daha yüksek olmaktadır. Bu ülkelerde finansal gelişme ile krediye ulaşma olanakları artan yoksullar karlı yatırımlarda bulunabilecek ve gelir eşitsizliği onlar lehine azalacaktır (Clarke, Xu, \& Zou, 2003: 3).

Finansın daha az gelişmiş olduğu durumda düşük gelirli bireyler, beşeri ve fiziksel sermayeye yatırım yapamamakta ya da borçlanmadıkları sürece yeni bir işe başlamak için gerekli başlangıç maliyetlerini kendi imkânlarıyla karşılayamamaktadırlar. Finansal piyasalar geliştikçe, düşük gelirli bireylerin fiziki ve beşeri sermaye için gereksinim duydukları fona ulaşmaları daha kolay hale gelmekte ve böylece daha az gelişmiş finansal piyasaların varlığında sahip olacakları refah düzeyinden daha yüksek bir refaha sahip olma olasılıkları artmaktadır. Diğer yandan yüksek gelir dilimindeki bireyler, finansal sektör gelişiminin seviyesi ne olursa olsun yatırım için kendi kaynaklarından yararlanabilmektedirler. Böylece gelişen finansal sistem yüksek gelirliler için olağanüstü firsatlar sunmazken, düşük gelirlilerin refahını artırmakta ve gelir eşitsizliğinin azalmasını sağlamaktadır (Clarke vd., 2006: 580-581). Demirgüç-Kunt ve Levin (2008) finansal piyasa kusurlarının yoksulların eğitim ya da beşeri sermaye düzeyini etkilediğini, böylece sürekli gelir eșitsizliğini teşvik ettiğini ileri sürmüştür. Demirgüç-Kunt ve Levin (2008)'e göre, mükemmel finansal piyasa koşulları altında akademik arzusu olan bireyler ebeveyn servetinden bağımsız olarak yeterli eğitim alabilmektedir. Bu kişinin ekonomik firsatının tamamen yeteneğine bağlı olduğunu göstermektedir. Aksine bilgi asimetrileri, işlem maliyetleri ve sözleşme yükümlülüğü gibi işlevlerde mükemmel olmayan finansal piyasa koşulları altında okullaşma sadece akademik arzu tarafından değil, aynı zamanda ebeveyn servetiyle de etkilenmektedir. Düşük gelirli ebeveynlerin çocuklarına eğitim vermek için ödünç para almaları gerekmektedir. Ancak finansal piyasalardaki kusurlar eğitimin finanse edilmesinde engeller yaratmakta ve akademik açılan yetenekli olan düşük gelirli bireyler eğitim almakta zorlanmaktadır. Daha varlıklı ebeveynleri olan nispeten daha az yetenekli bireyler ise iyi bir eğitim alabilmektedir. Dolayısıyla, kusurlu finansal piyasa koşullarında kişinin beşeri sermaye düzeyi ve ekonomik firsatları sadece kişinin yeteneği ile değil, aynı zamanda ebeveyn serveti ile belirlenmektedir. Sonuç olarak, kusurlu bir finansal piyasada eğitimi finanse etmenin önündeki engeller düşük gelirli bireylerin aleyhine olarak gelir eşitsizliğini arttırırken, finansal gelişme düşük gelirli bireylerin beşeri sermayeleri için finansman bulmalarına olanak sağlayarak onların lehine gelir eşitsizliğini azaltmaktadır. Finansal piyasalar geliş̧ikçe önceden finansmana erişimi olmayan düşük gelirli bireylerin bu gelişimden asıl fayda sağlayanlar olacağını ve böylece gelir eşitsizliğinin azalacağını ileri süren bu yaklaşımlar, literatürde "Eşitsizlik Yakınsama Hipotezi" olarak adlandırılmaktadır.

Teorinin finansal gelişme ve gelir eşitsizliği ilişkisi üzerine sunduğu bu çelişkili durumlar ampirik çalışmaların da çelişkili sonuçlar sunmasıyla birlikte, konuya ilişkin fikir birliğine ulaşılmasının önüne geçmektedir. Örneğin Beck, Demirgüç-Kunt ve Levine (2007) çalışmalarında "Eşitsizlik Yakınsama Hipotezi”nin geçerli olduğu sonucuna ulaşırken, Lundberg ve Squire (2003), Sehrawat ve Giri (2015), Ahsan ve Masih (2016) ile De Haan ve Sturm (2017) "Eşitsizlik Arttırıcı Hipotez"in geçerli olduğu sonucuna ulaşmışlardır Bahmani-Oskooee ve Zhang (2015) ise farkı ülkeler için karma sonuçlara ulaşmıştır. Finansal gelişme ve gelir eşitsizliğine ilişkin yukarıda açılanan teorik çerçeveye uygun kanıtlara ulaşan bu çalışmaların dışında, Law ve Tan (2009) gibi finansal gelişme ve gelir eşitsizliği arasında herhangi bir ilişsiye ulaşamayan çalışmalar da mevcuttur. Ancak finansal gelişme ve gelir eşitsizliği ilişkisi hakkında temel olarak yukarıda açıklanan üç farklı hipoteze ilişkin argümanlar bulunmaktadır. Bu çalışmada Türkiye'de bu üç hipotezi test etmek için, 1987-2017 yılları için oluşturulan bir zaman serisi kullanılmıştır. Eğer "Eşitsizlik Yakınsama Hipotezi”" doğruysa, finansal gelişimin artması eşitsizliği azaltacaktır. Eğer "Eşitsizlik Arttırııı Hipotez" doğruysa, finansal gelişimin

$82 \mid P$ a g e

www.iiste.org 
artması eşitsizliği arttıracaktır. Eğer “Ters-U Hipotezi” doğruysa, finansal gelişmenin ilk aşamalarında gelir eşitsizliği artacak, ancak belirli bir eşik düzeyden sonra azalacaktır (Clarke vd., 2006: 581).

\section{Ampirik Literatür}

Finansal gelişme ve gelir eşitsizliği arasındaki ilişkiyi inceleyen ampirik çalş̧malar Tablo 1'de özet olarak sunulmuş ve literatürde bu ilişkileri incelemek üzere kullanılan değişkenler, araştırılan ülke grupları, incelenen zaman dilimi ve kullanılan yöntemler bir bütün olarak değerlendirilmiş̧tir.

Tablo 1. Finansal gelişme ve gelir eşitsizliği arasındaki ilişkiyi inceleyen çalışmalar

\begin{tabular}{|c|c|c|c|c|c|c|}
\hline 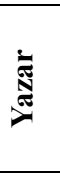 & 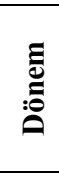 & $\stackrel{\mathscr{s}}{:}$ & & 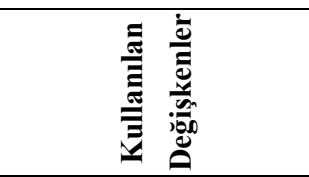 & 离 & $\begin{array}{l}\mathscr{\Xi} \\
\stackrel{\Xi}{E}\end{array}$ \\
\hline 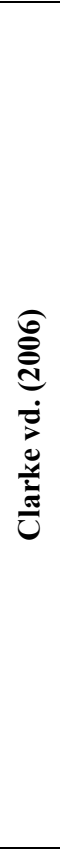 & $\begin{array}{l}\approx \\
\alpha \\
\frac{1}{2} \\
\stackrel{2}{2}\end{array}$ & 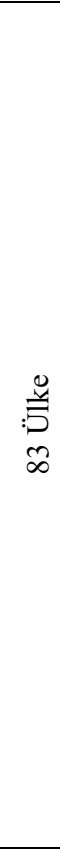 & $\begin{array}{l}n \\
\text { ज } \\
\text { त } \\
0 \\
3 \\
\text { n } \\
0\end{array}$ & 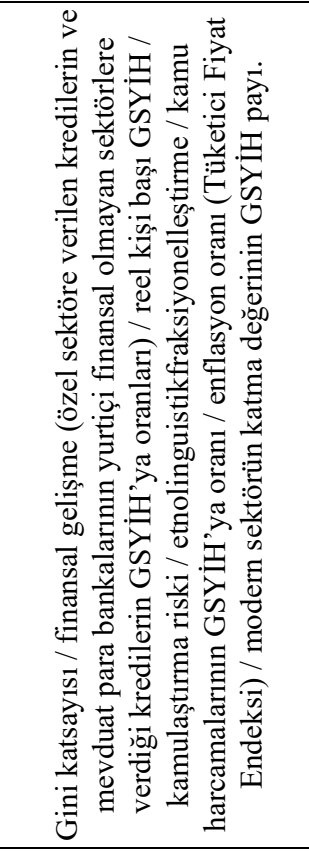 & 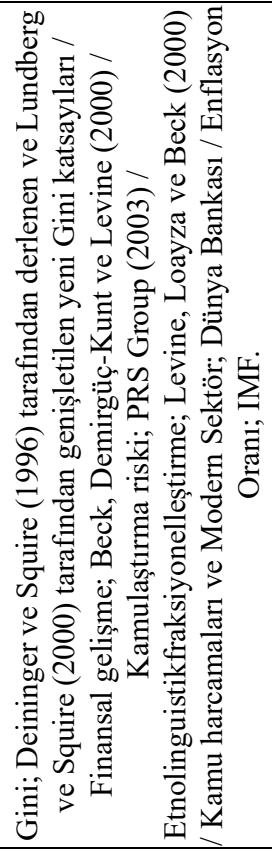 & 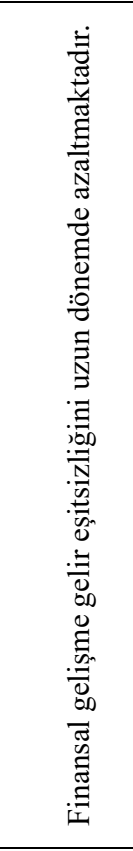 \\
\hline 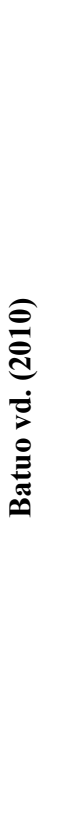 & $\begin{array}{l}\text { ¿े } \\
\text { 1े } \\
\text { ○े }\end{array}$ & 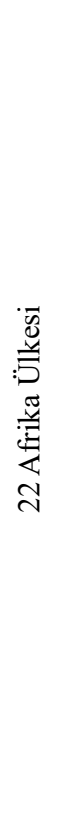 & $\sum_{j}$ & 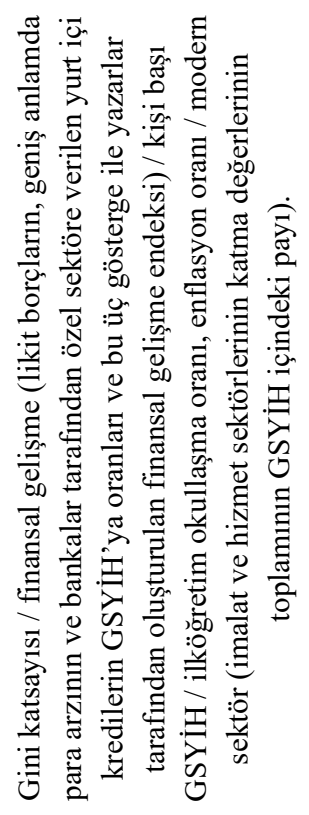 & 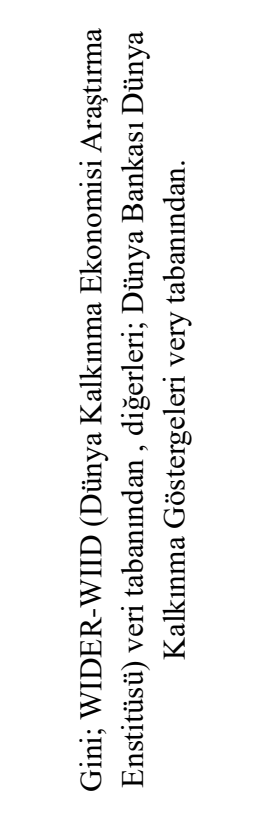 & 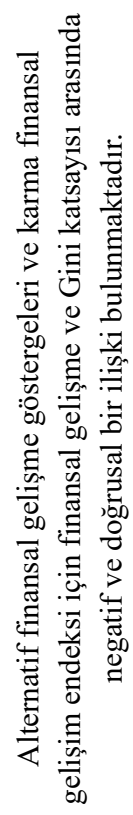 \\
\hline
\end{tabular}

83 | P a g e 


\begin{tabular}{|c|c|c|c|c|c|c|}
\hline 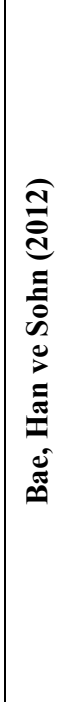 & 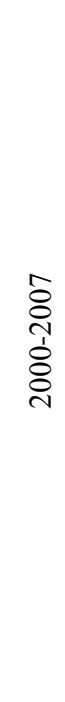 & 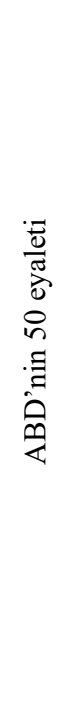 & $\sum_{\Psi}^{\Sigma}$ & 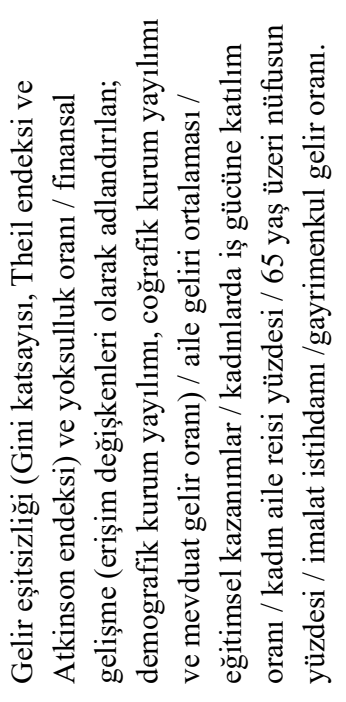 & 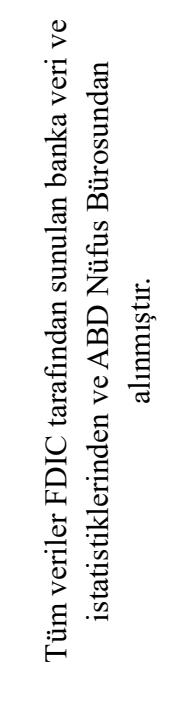 & 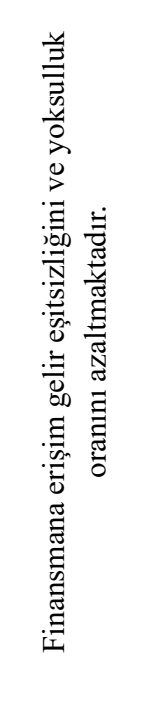 \\
\hline 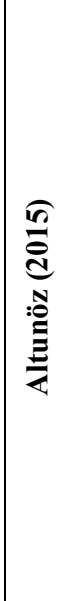 & 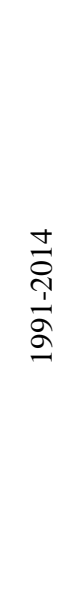 & 竟 & 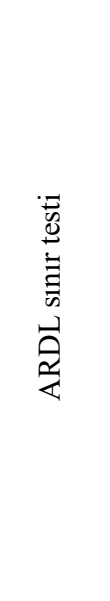 & 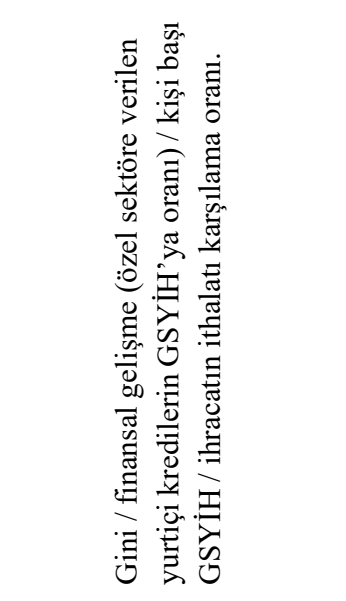 & 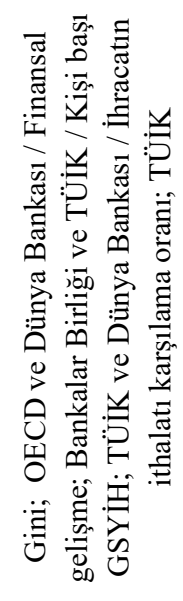 & 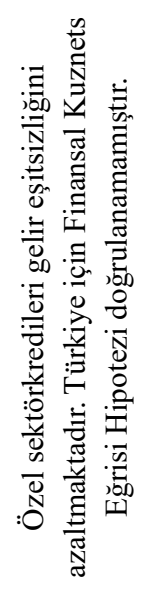 \\
\hline 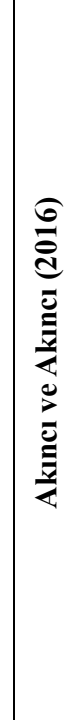 & 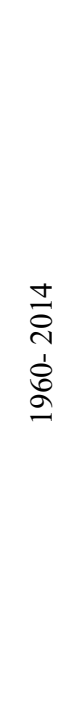 & 兽 & 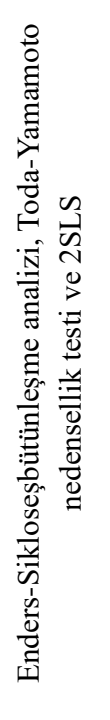 & 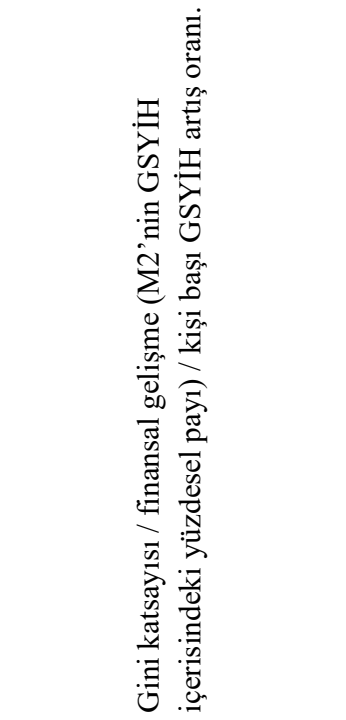 & 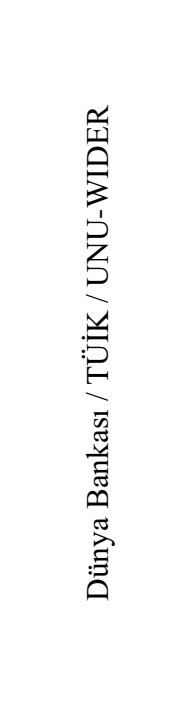 & 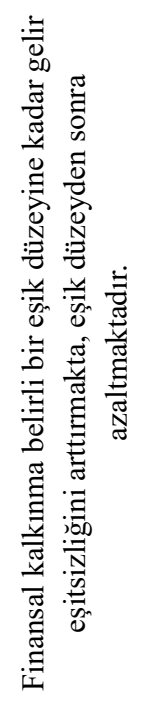 \\
\hline
\end{tabular}




\begin{tabular}{|c|c|c|c|c|c|c|}
\hline 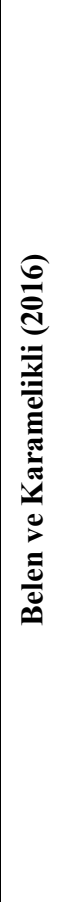 & 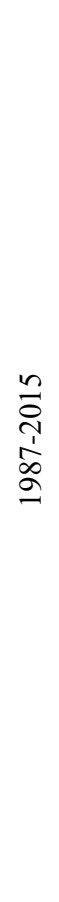 & 离 & 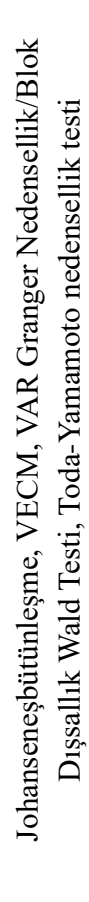 & 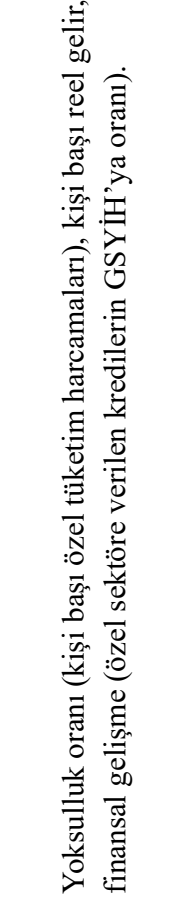 & $\sum_{i}^{T}$ & 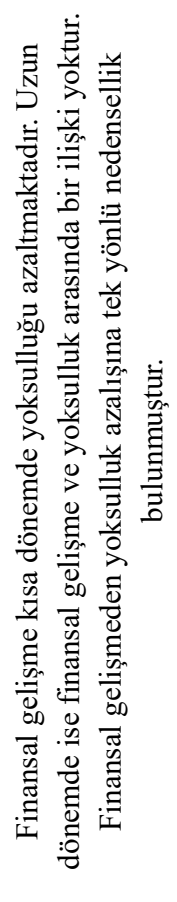 \\
\hline 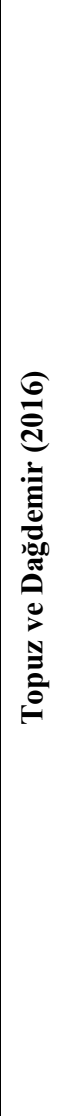 & 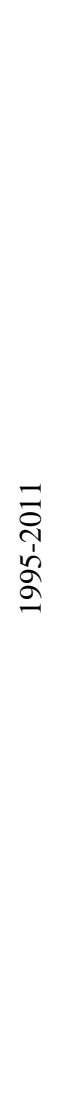 & 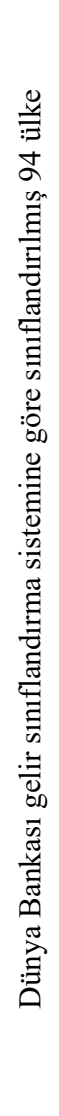 & 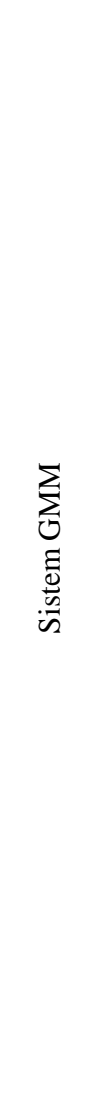 & 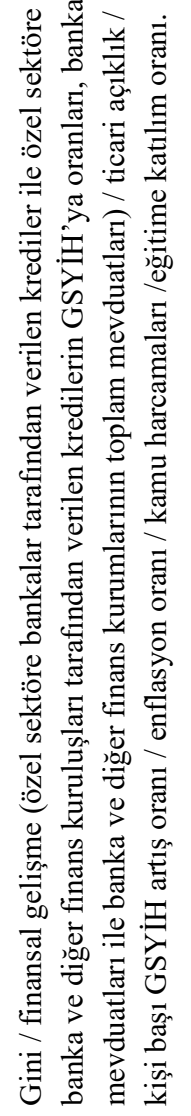 & 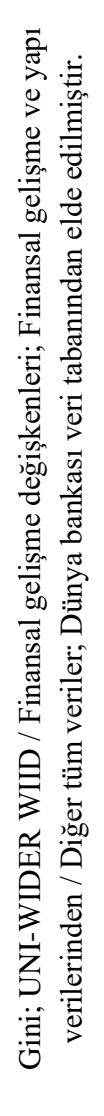 & 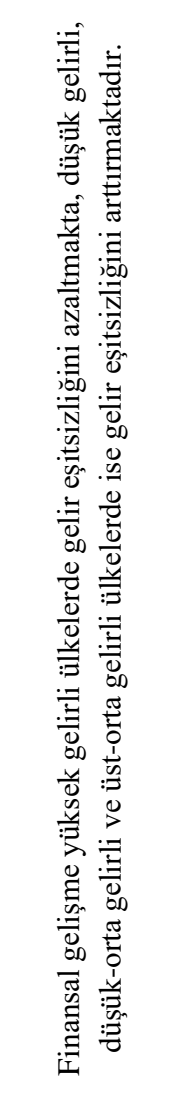 \\
\hline
\end{tabular}


Vol.7, No.1, 2021

\begin{tabular}{|c|c|c|c|c|c|c|}
\hline 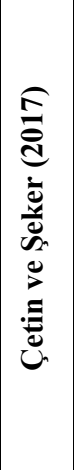 & 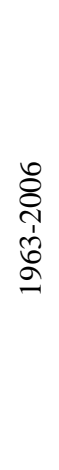 & 忞 & 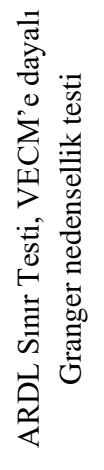 & 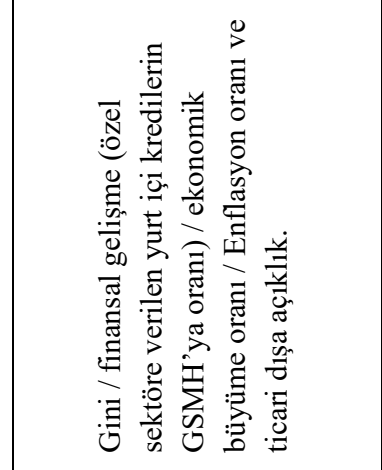 & 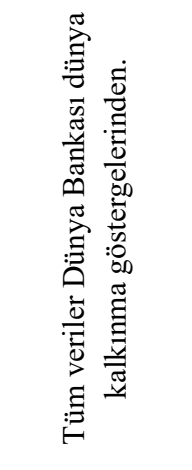 & 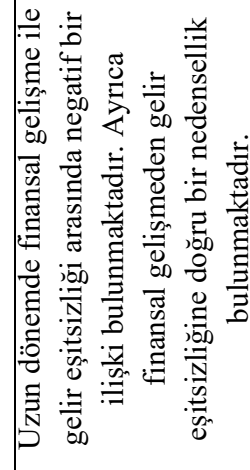 \\
\hline 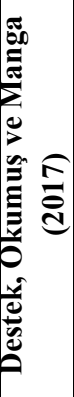 & $\begin{array}{l}\text { à } \\
\text { 1 } \\
\stackrel{1}{a} \\
a\end{array}$ & 吝 & 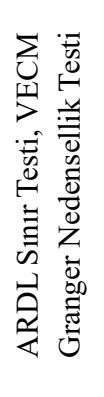 & 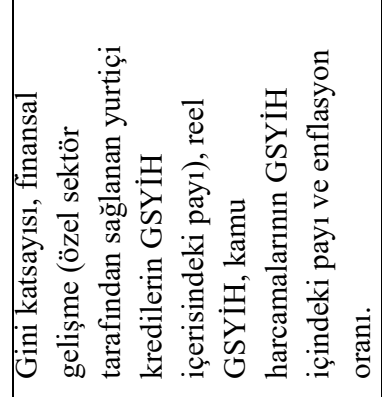 & 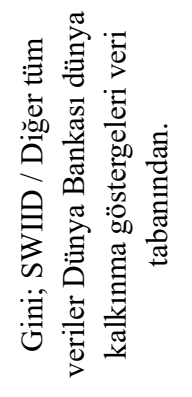 & 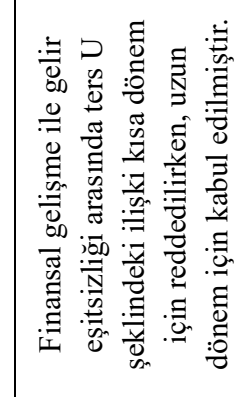 \\
\hline 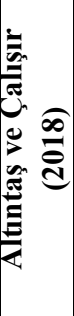 & 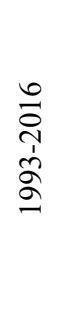 & 逽 & 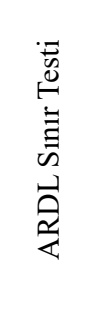 & 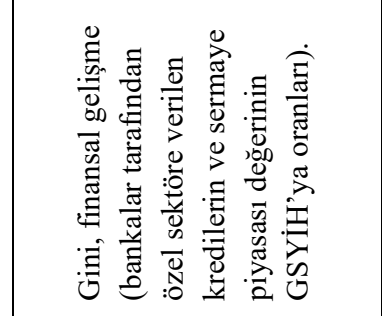 & 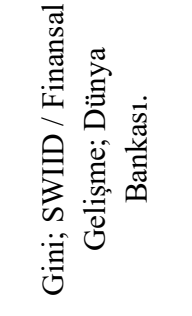 & 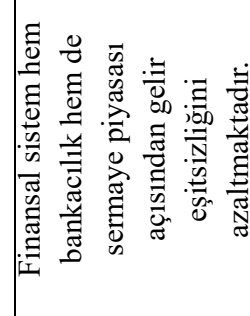 \\
\hline 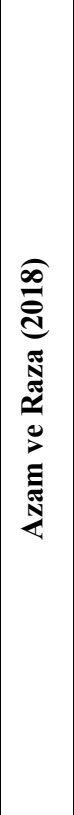 & $\begin{array}{l}\overrightarrow{\widehat{N}} \\
\stackrel{1}{\circ} \\
\stackrel{2}{\Omega}\end{array}$ & 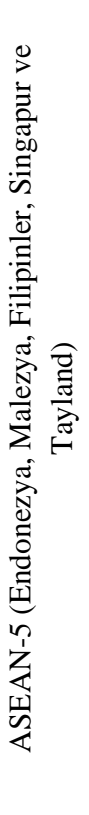 & 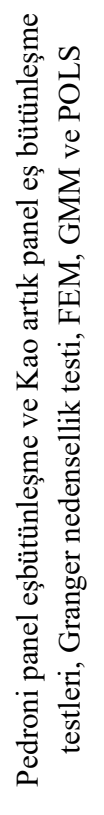 & 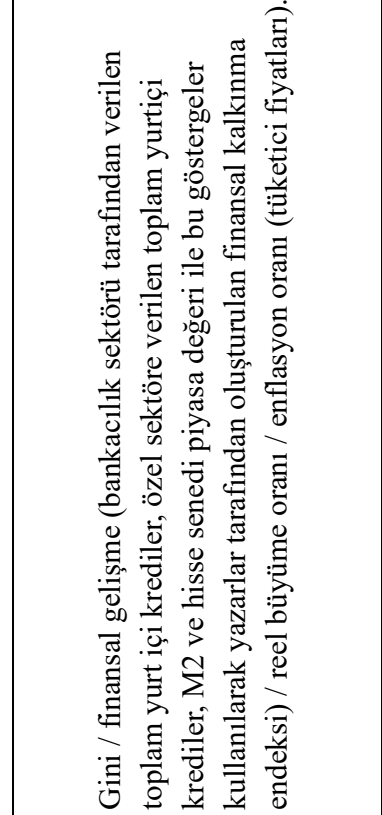 & 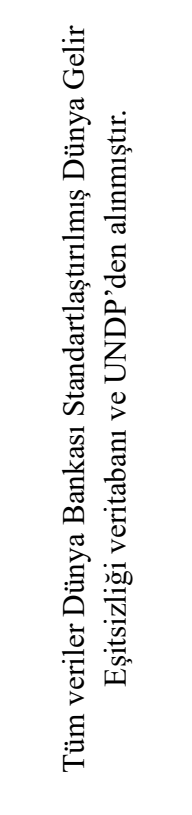 & 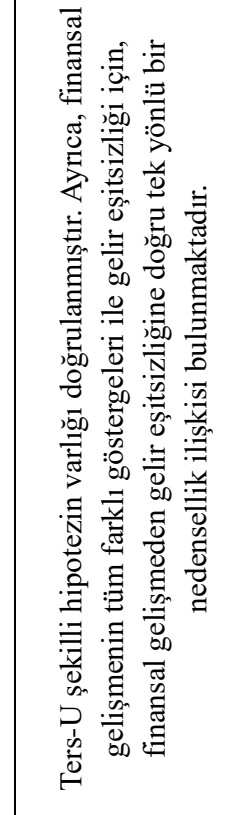 \\
\hline
\end{tabular}




\begin{tabular}{|c|c|c|c|c|c|c|}
\hline 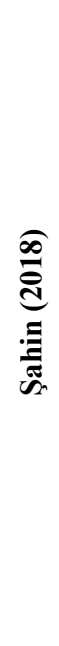 & 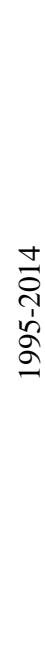 & 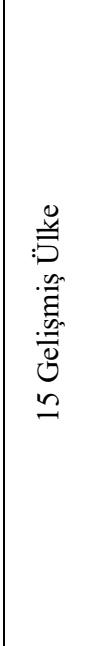 & 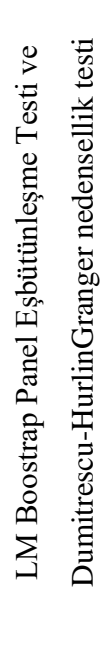 & 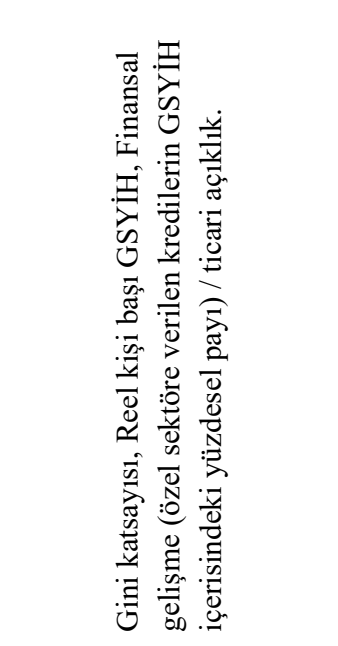 & 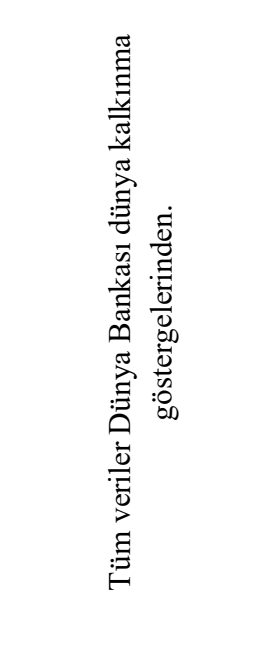 & 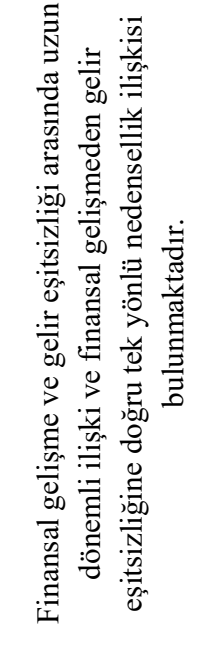 \\
\hline 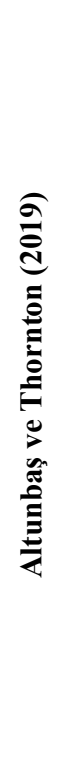 & 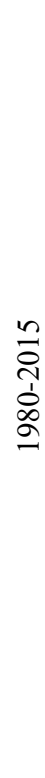 & 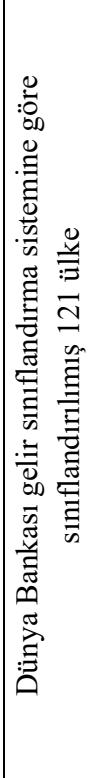 & $\begin{array}{l}\sum_{0} \\
0 \\
\sum_{i=1}^{0} \\
\sum_{i=1}^{+}\end{array}$ & 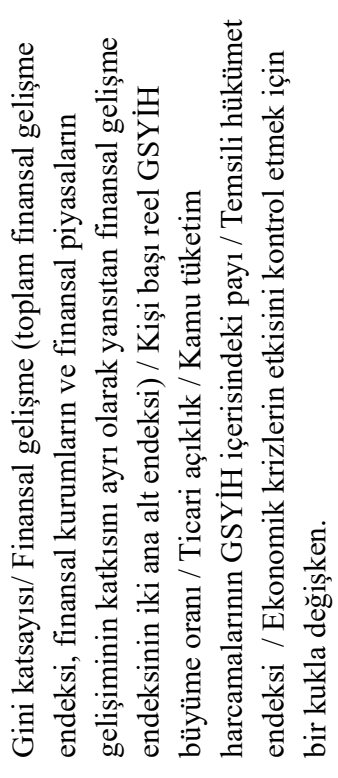 & 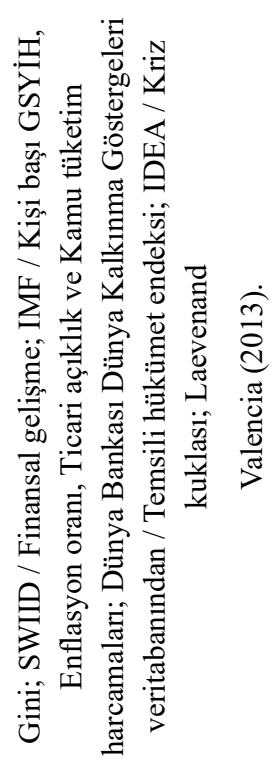 & 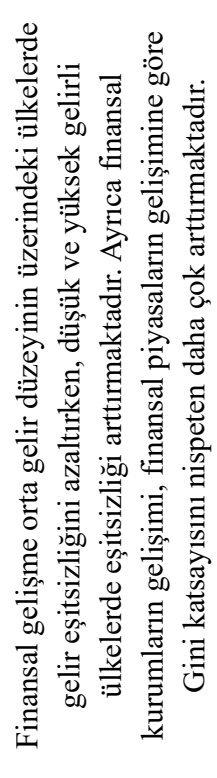 \\
\hline 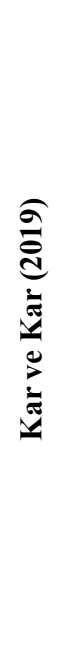 & $\begin{array}{l}\text { 尺े } \\
\text { ঠे } \\
\text { }\end{array}$ & 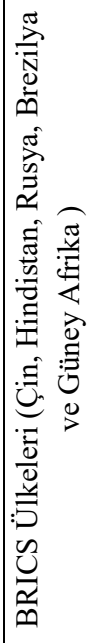 & 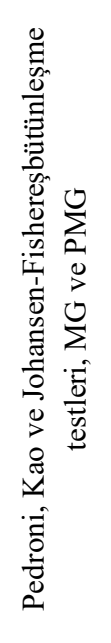 & 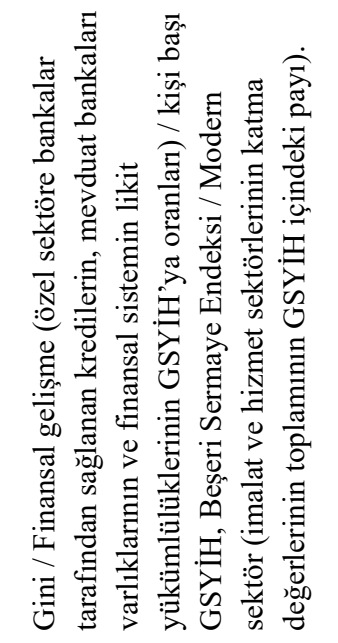 & 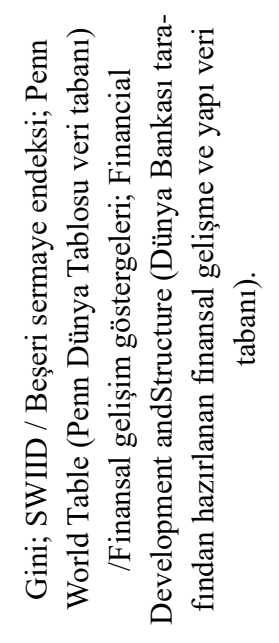 & 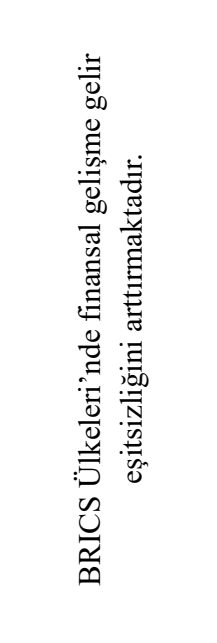 \\
\hline
\end{tabular}


Vol.7, No.1, 2021

\begin{tabular}{|c|c|c|c|c|c|c|}
\hline 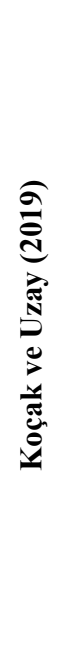 & $\begin{array}{l}m \\
\stackrel{2}{1} \\
\stackrel{1}{ } \\
\stackrel{0}{a}\end{array}$ & 胥 & 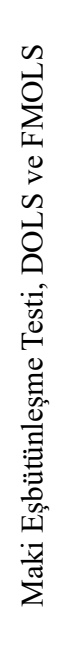 & 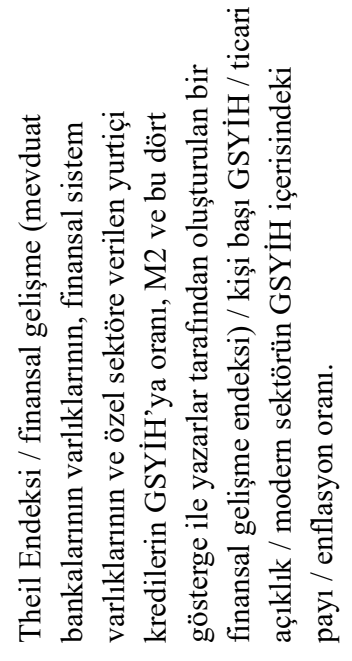 & 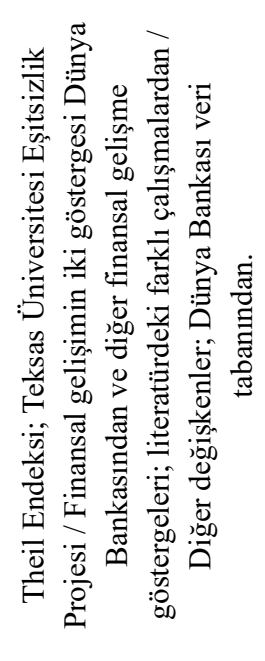 & 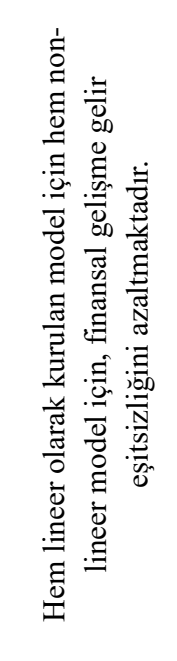 \\
\hline 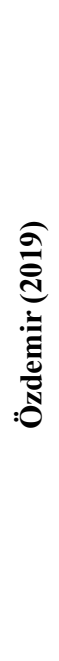 & 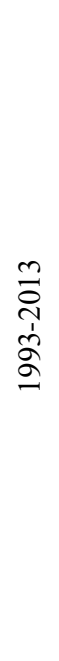 & $\begin{array}{l}\stackrel{0}{5} \\
: \\
\sigma\end{array}$ & $\begin{array}{l}\sum_{j} \\
\sum_{i=1}^{D} \\
\sum\end{array}$ & 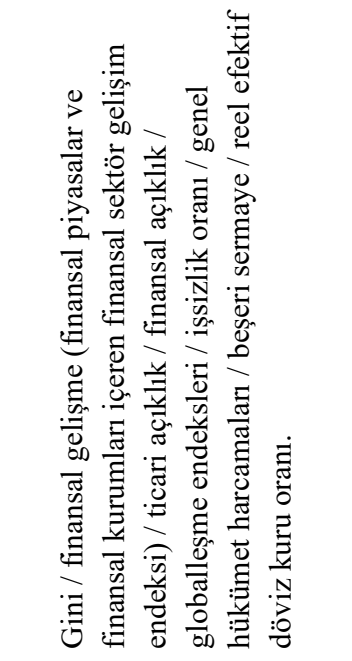 & 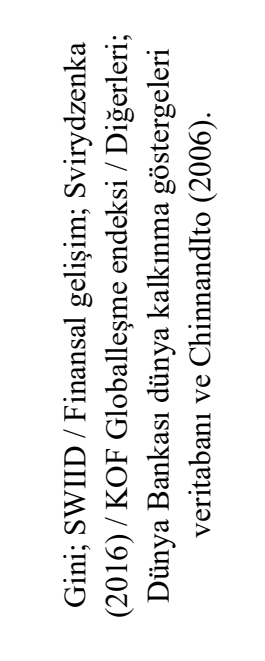 & 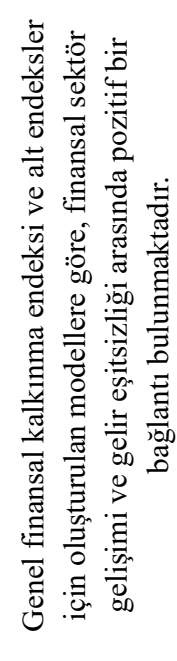 \\
\hline 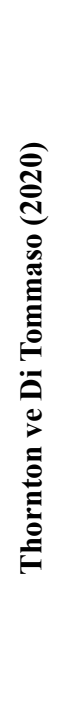 & 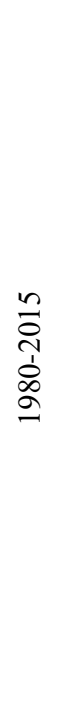 & 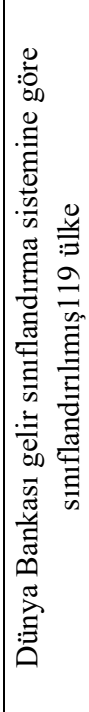 & 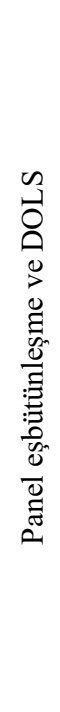 & 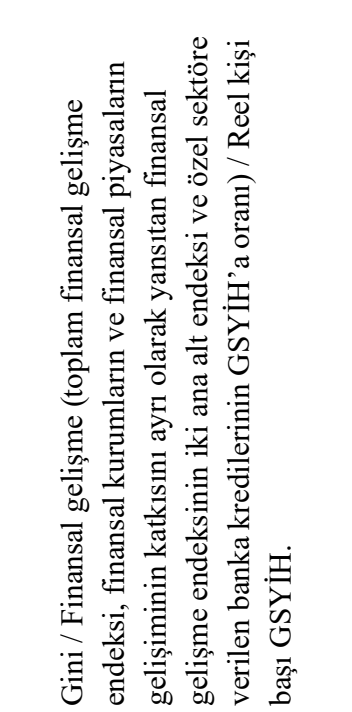 & 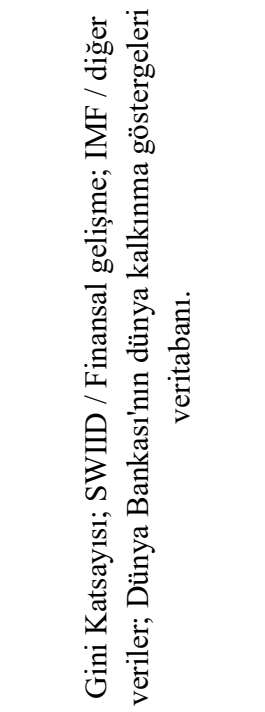 & 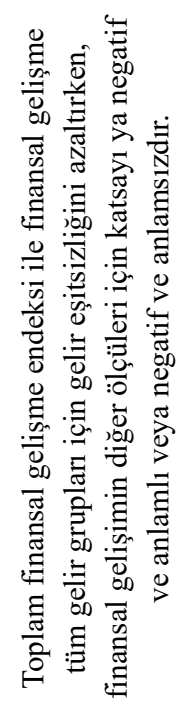 \\
\hline
\end{tabular}




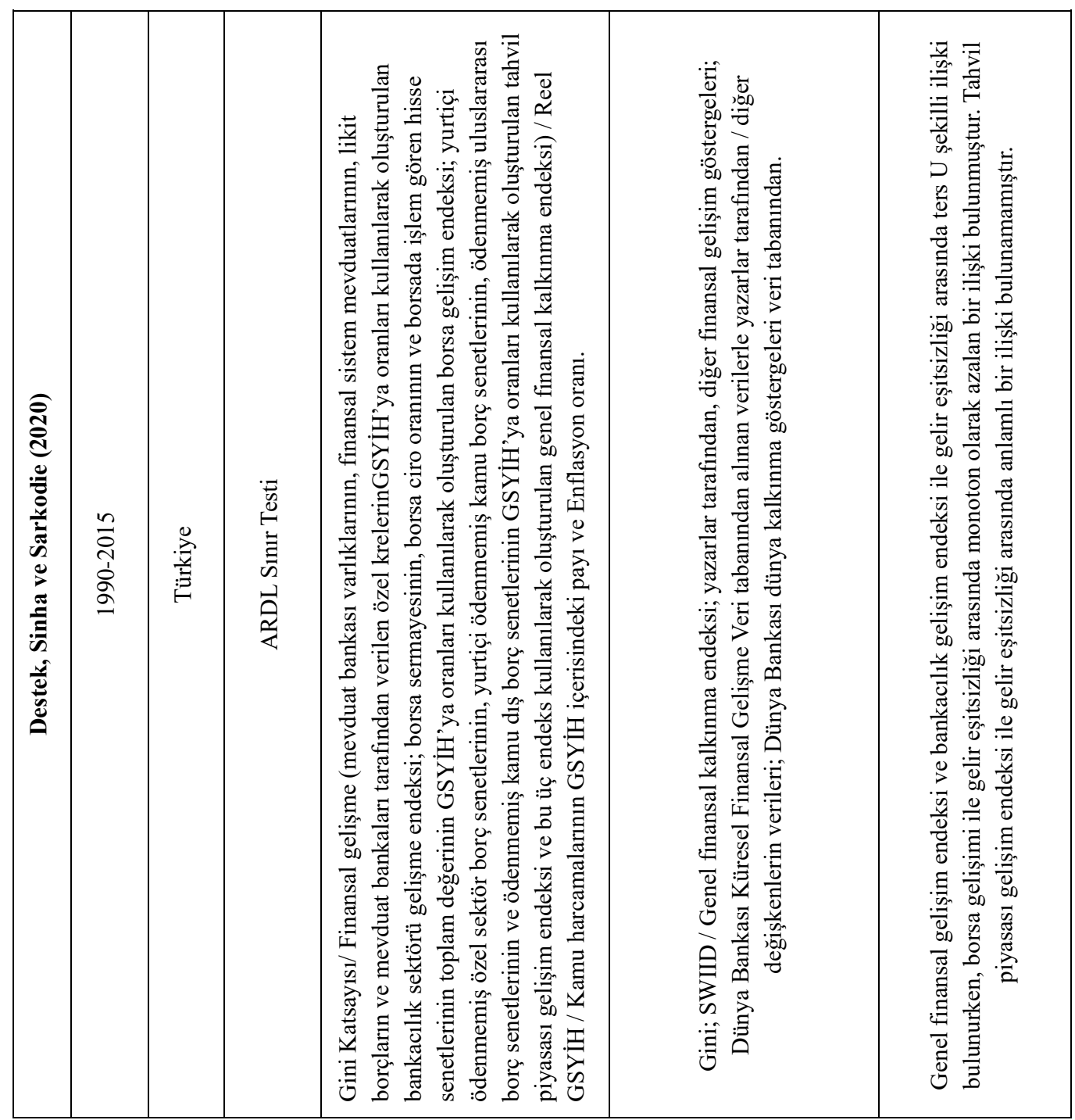

Kısaltmalar: ARDL Sınır Testi=Gecikmesi Dağıtılmış Otoregresif Sınır Testi, DOLS=Dinamik Sıradan En Küçük Kareler Yöntemi, FEM=Sabit Etkiler Modeli, FMOLS=Tam Düzeltilmiş En Küçük Kareler Yöntemi, GMM=Genelleştirilmiş Momentler Yöntemi, MG=Ortalama Grup Tahmincisi, OLS=Sıradan En Küçük Kareler Yöntemi, PMG=Havuzlanmış Ortalama Grup Tahmincisi, POLS=Havuzlanmış Sıradan En Küçük Kareler Yöntemi, REM=Tesadüfî Etkiler Modeli, VAR=Vektör Otoregresif Regresyon, VECM=Vektör Hata Düzeltme Modeli ve 2SLS=Iki Aşamalı En Küçük Kareler Yöntemidir.

Gini=Gelir Eşitsizliğini Temsil Eden Katsayı, M2=Geniş Anlamda Para Arzı, GSYİH=Gayrisafi Yurtiçi Hasıla, GSMH=Gayrisafi Milli Hasıladır.

$\mathrm{ABD}=$ Amerika Birleşik Devletleri, FDIC=Federal Mevduat Sigortası Şirketi, IDEA=Uluslar Arası Demokrasi ve Seçim Yardım Enstitüsü, IMF=Uluslararası Para Fonu, $\mathrm{OECD}=$ Ekonomik İşbirliği ve Kalkınma Örgütü, SWIID=Standartlaştırılmış Dünya Gelir Eșitsizliği Veri Tabanı, TÜIK=Türkiye İstatistik Kurumu, UNDP= Birleşmiş Milletler Geliş̧tirme Programı, UNU-WIDER= Birleşmiş Milletler Üniversitesi Dünya Kalkınma Ekonomisi Araştırma Enstitüsü ve WIID=Dünya Gelir eşitsizliği Veri Tabanıdır.

Finansal gelişme ve gelir eşitsizliğini araştıran ampirik literatürün, hem ülkeler bazında hem aynı ülke örnekleri için çelişkili kantlar sunduğu görülmektedir. Ampirik literatürden elde edilen bu farklı sonuçların; 1) finansal gelişme ve gelir eşitsizliği arasında herhangi bir ilişki bulunmadığı, 2) finansal gelişme ile gelir eşitsizliğini arasında doğrusal ve pozitif bir ilişki bulunduğu, 3) finansal gelişme ve gelir eşitsizliği arasında doğrusal ve negatif bir ilişki bulunduğu ve 4) finansal gelişme ve gelir

89 | P a g e

www.iiste.org 
eşitsizliği arasında ters-U şeklinde bir ilişki bulunmadığını gösterecek şekilde genel olarak dört argüman altında toplandığı dikkati çekmektedir. Ancak bu dört argüman çalışmanın teorik kısmında ele alındığı gibi "Eşitsizlik Yakınsama Hipotezi" ve "Ters-U Hipotezi" temelinde değerlendirilebilmektedir.

\section{Model ve Veri}

Çalışmanın bu bölümünde 1987-2017 yılları arasında Türkiye'de finansal gelişme ve gelir eşitsizliği ilişkisine dair ampirik kanıtlar sunulmak üzere oluşturulan model ve kullanılan veriler tanımlanmaktadır. Çalışmada kullanılan zaman aralığı verilerin ulaşılabilirliği göz önünde bulundurularak seçilmiştir. Çalışmada Türkiye'de finansal gelişme ile gelir eşitsizliği arasındaki ilişkinin Greenwood ve Jovanovic (1990)'in ileri sürdüğü gibi ters-U şeklinde mi yoksa Banerjee ve Newman (1993) ve Galor ve Zeira, (1993)'nın ileri sürdüğü gibi doğrusal bir ilişki mi olduğunu incelemek amacıyla Batuo vd. (2010) oluşturulan kuadratikmodel aşağıdaki gibidir:

$\operatorname{Gini}_{t}=\beta_{1}+\beta_{2}$ Fin $_{t}+\beta_{3}$ Fin $_{t}^{2}+\beta_{j} X_{j t}+u_{t}$

Eşitlik (1)'de bağımlı değişken Gini $_{t}$ gelir eşitsizliğini temsil ederken, $t$ ise ilgili yılı göstermektedir. Gini katsayısı, gelirleri standartlaştırarak ülkeler arasında karşılaştırmaları kolaylaştıran Solt (2020)'un Standart Dünya Gelir Eşitsizliği veri tabanından (SWIID) elde edilmiştir. Bu veri tabanında eşitsizlik katsayısı brüt ve net olarak ölçülmektedir. Eşitsizlik katsayısının hem brüt hemde net olarak temsil edilmesi, SWIID’e diğer eşitsizlik ölçüleri sunan very tabanlarına göre özel bir önem katmaktadır. Bu çalışmada, vergilerden arındırılmamış gayri safi hanehalkı gelirindeki eşitsizliği gösteren Gini katsayısı kullanılmıştır. De Haan ve Sturm (2016)'a göre gelir eşitsizliğinin vergi ve transferlerden önceki gelirle ölçülmesi durumunda, bu ölçüm maliye politikası dışındaki gelir eşitsizliğini gösterecektir. " 0 " ile "100" arasında ölçeklendirilen bu verilerin sıfırdan itibaren artan değerler alması gelir eşitsizliğinin artması anlamına gelirken, " 0 " mükemmel eşitliği ve " 100 ” ise mükemmel eşitsizliği temsil etmektedir. $F_{i n}$ finansal gelişme endeksini ve Fin $_{t}^{2}$ ise finansal gelişme ve gelir eşitsizliği arasında ters U şeklinde bir ilişkiyi öngören Finansal Kuznets Hipotezinin varlığını test etmek için kullanılan finansal gelişme endeksinin karesini temsil etmektedir. Finansal gelişme, Fin, Svirydzenka (2016)'nın genel finansal gelişme endeksi ile ölçülmüştür. Finansal gelişmeyi temsil eden bu genel endeks, farklı soyutlama düzeylerinde geliştirilmiş, ülkelerin finansal sistemlerini değerlendiren her biri altı adet alt endeks düzeyinde hesaplanan iki temel alt endeksin (finansal piyasalar ve finansal kurumlar) ağırlıklı ortalamasını yansıtmaktadır ${ }^{1}$. Bu endeksi kullanmanın arkasındaki temel gerekçe, bu endeksin alt endekslerinin finansal piyasalar ve finansal kurumları derinlik, erişim ve etkinliğini de ölçmesi ve böylece finansal gelişimin gelir eşitsizliği üzerindeki etkilerini bütün boyutlarıyla tahmin edebilmektir. Finansal piyasalar ve finansal kurumların derinlik ve erişim gibi alt boyutlarının ihmal edilmesi, finans ve gelir eşitsizliği ilişkisinin kısıtlı bir şekilde anlaşılmasına neden olmaktadır. Çünkü finansal piyasalar ve finansal kurumlar bir bütün olarak finansal hizmetlerin sunumunu kolaylaştırmaktadır (Svirydzenka, 2016: 4). Finansal Kuznets Hipotezinin varlığının doğrulanabilmesi için eşitlik (1)'de finansal gelişme endeksine ait katsayının $\left(\beta_{2}\right)$ pozitif, finansal gelişme endeksinin karesine ait katsayının $\left(\beta_{3}\right)$ negatif olması gerekmektedir $\left(\beta_{2}>0\right.$ ve $\left.\beta_{3}<0\right)$. Eşitsizlik Yakınsama Hipotezinin geçerli olması için finansal gelişme endeksine ait katsayının $\left(\beta_{2}\right)$ negatif ve finansal gelişme endeksinin karesine ait katsayının $\left(\beta_{3}\right)$ da sıfır ya da sıfırdan küçük olması gerekmektedir $\left(\beta_{2}<0\right.$ ve $\left.\beta_{3} \leq 0\right)$. Eşitsizlik Arttırıcı Hipotezin geçerli olması için ise, finansal gelişme endeksine ait katsayının $\left(\beta_{2}\right)$ pozitif ve finansal gelişme endeksinin karesine ait katsayının $\left(\beta_{3}\right)$ da sıfır ya da sıfırdan büyük olması gerekmektedir $\left(\beta_{2}>0\right.$ ve $\left.\beta_{3} \geq 0\right)$.

Finansal gelişme ve gelir eşitsizliğini inceleyen modelimize ayrıca literatürde gelir eşitsizliğinin belirleyicileri olarak sıklıkla kullanılan kontrol değişkenleri eklenmiştir. Eşitlik (1)'deki $X_{j t}$ terimi,

\footnotetext{
${ }^{1} \mathrm{Bu}$ endeksler; (i) Finansal kurumlara erişimi, bu kurumların verimliliğini (faiz marjı, yaygınlık ve aktif getirisini) ve bu kurumların derinliğini (krediler, emeklilik fonları ve yatırım fonu varlıkları) ölçen finansal kurumlar endeksi (FI), (ii) Finansal piyasaların derinliğini (borsa sermaye miktarı, hisse senedi ticareti ve borçlanma senetleri), sermaye piyasalarına erişimini (sermaye miktarı ve borç verenler) ve finansal piyasaların verimliliğini (devir hızı) ölçen finansal piyasalar endeksi (FM) ve (iii) Temel bileşenler analizi kullanılarak elde edilen ağırlıklarla, FI ve FM endeksilerinin ağırlıklı ortalamalarından oluşan genel finansal gelişme endeksidir (FD). Ayrıntılar için, bkz. Svirydzenka (2016).
}

90 | P a g e

www.iiste.org 
modele eklenen bu kontrol değişkenlerini temsil eden vektördür.Bu vektörün temsil ettiği değişkenler; (1) GOVRN; kamu nihai tüketim harcamalarının GSYİH içindeki yüzdesel payı (temsili bir hükümet endeksi), (2) MODERN; modern sektörün temsilcisi olarak sanayi, imalat ve hizmet sektörlerinin toplam katma değerlerinin GSYİH içindeki yüzdesel payı, (3) HUMANCAP; beşeri sermaye endeksi, (4) $I N F$; enflasyon oranı (Tüketici Fiyat Endeksi, yıllık \%) ve (5) $T L$; ticari açıklıktır (ithalat artı ihracatın GSYIH içindeki yüzdesel payı). Modeldeki $\mu_{\mathrm{t}}$ ise hata terimini temsil etmektedir. Kullanılan tüm değişkenler modele logaritmik formda dahil edilmiştir. Böylece katsayılar, açıklayıcı değişkenlerin gelir eşitsizliği üzerindeki esnekliklerini vermektedir (Topuz \& Dağdemir, 2016: 27). Değişkenlerin ve veri kaynaklarının özeti Tablo 2'de verilmiştir.

Tablo 2. Değişken tanımları ve veri kaynakları

\begin{tabular}{|lll|}
\hline Değişken & Tanım & Kaynak \\
\hline GINI & $\begin{array}{l}\text { Gelir eşitsizliğini ölçen Ginikatsayısı, 0 mükemmel derecede } \\
\text { eşitliği ve 1 en eşitsiz durumu göstermek üzere 0 ve 1 arasında } \\
\text { değerler almaktadır. Katsayı, vergi öncesihanehalk1 } \\
\text { harcanabilir gelirine dayanmaktadır. }\end{array}$ & $\begin{array}{l}\text { (Solt, 2020) } \\
\text { /SWIID }\end{array}$ \\
\hline FD & $\begin{array}{l}\text { Finansal kurumların ve finansal piyasaların ne kadar derin, } \\
\text { erişilebilir ve verimli olduğunu ölçmek için altı seviye ile } \\
\text { oluşturulan iki alt endeksin (finansal kurumlar- ve finansal } \\
\text { piyasalar), ağırlıklı toplamları alınarak finansal gelişmenin } \\
\text { genel bir ölçütü olan finansal gelişme endeksi (FD) }\end{array}$ & (IMF) \\
\hline GOVRN & $\begin{array}{l}\text { Genel hükümet nihai tüketim harcamalarının GSYïH içindeki } \\
\text { yüzdesel payı }\end{array}$ & (WDI) \\
\hline MODERN & $\begin{array}{l}\text { Sanayi, imalat ve hizmet sektörü katma değerinin GSYïH } \\
\text { içindeki yüzdesel payı }\end{array}$ & (WDI) \\
\hline HUMANCAP & Beşeri sermaye endeksi & (PWT) \\
\hline INF & Enflasyon oranı (tüketici fiyatları,yıllık \%) & (WDI) \\
\hline TL & $\begin{array}{l}\text { Ticari açıklık (ithalat ve ihracat toplamının GSYİH içindeki } \\
\text { yüzdesel payı) }\end{array}$ & (WDI) \\
\hline
\end{tabular}

Not: SWIID; Standartlaştırılmış Dünya Gelir Eşitsizliği Veritabanı, IMF; Uluslararası Para Fonu, WDI; Dünya Bankası Dünya Kalkınma Göstergeleri Veritabanı, PWT; Penn World Table, version: 9.

Ticari açıklık ve büyüme ilişkisine dair literatür incelendiğinde, genel kanının liberalizasyonun ekonomik büyümeyi arttıracağı yönünde olduğu görülmektedir. Bu bağlamda, ticari açıklı̆̆ın büyümeyi ve dolayısıyla gelir eşitsizliğini azaltacağ 1 varsayılarak $T L$ değişkeninin katsayısının negatif olması beklenmektedir (Altunbaş \& Thornton, 2019: 2). Enflasyonun yoksul ve orta sinıfin ücret ya da transferlerinin reel değerini azaltarak onlara verdiği zarar (Romer \& Romer, 1998), finansal araçlara daha iyi erişimleri olduğu için enflasyondan nispeten korunabilen zenginlere göre daha fazladır (Clarke vd., 2006: 585). Bu nedenle enflasyonu temsil eden INF değişkeninin katsayısının pozitif olması beklenmektedir.

Beşeri sermaye endeksi, eğitim süresi ve eğitimden sağlanan getirilere dayalı olarak hesaplanmıştır ve Penn World Table veri tabanından elde edilmiştir. Eğitimdeki bir artış; vasıflı işgücünün artışı, vasıfl1/vasıfsız işçi ücretlerinde nispi bir azalma ve sonuç olarak genel gelir eşitsizliğinde bir azalma anlamına gelmektedir. Dolayısıyla, beşeri sermaye endeksini temsil eden HUMANCAP değişkenine ait katsayının beklenen işareti negatiftir (Kar \& Kar, 2019: 33; Batuo vd., 2010: 12).

Kuznets (1955), gelir eșitsizliğinin ekonomideki sektör yapısına bağlı olabileceğini ileri sürmüștür. Bu nedenle çalışmaya, hizmetler, imalat ve sanayi sektörlerinin (yani tarım dışı sektörün) katma değerlerinin GSYİ içerisindeki yüzdesel payını temsil eden bir değişken olarak modern sektör eklenmiştir. Bu değişkenin GSYIH içerisindeki payının azalması, ülkede tarım dışı sektörün payının azaldığı ve yoksulluğun arttığı anlamına gelmektedir. Dolayısıyla, $M O D E R N$ değişkenine ait katsayının beklenen işareti de negatiftir. Hükümetin nihai tüketiminin gelir eşitsizliği üzerindeki etkisi ise diğer değişkenlere göre daha belirsizdir. Eğer zengin hane halkı siyasi güçlerini yoksulları sömürmek için

91 | P a g e

www.iiste.org 
kullanırlarsa hükümet tüketimi gelir eşitsizliğini arttıracak, yoksullar zenginlerin sömürüsüne karş1 korunursa eşitsizlik azalacaktır (Clarke vd., 2006: 585).

\section{Ampirik Bulgular}

Çalışmanın bu bölümünde, Türkiye'de 1987-2017 dönemindegelir eşitsizliği ile finansal gelişme arasındaki ilişkileri incelemek için oluşturulan model (Eşitlik 1), Peseran, Shin ve Smith (2001) tarafindan geliştirilen Otoregresif Dağıtılmış Gecikme Modeli (ARDL) testi kullanılarak tahmin edilmiştir. Eş bütünleşmenin incelenmesinde ARDL yaklaşımı kullanmanın bazı avantajları bulunmaktadır. Örneğin, ARDL sınır testinde değişkenlerin $\mathrm{I}(0)$ ya da $\mathrm{I}(1)$ derecelerinde durağanlaşıp durağanlaşmaması bu testin işleyişi açısından sorun oluşturmamaktadır. Bu yöntemin ikinci bir avantajı ise, küçük örnekler için elde edilen tahminlerde tutarlı sonuçlar vermesidir. Monte Carlo araştırması bu yaklaşımın küçük örnekler için tutarlı sonuçlar verdiğini göstermiş̧ir. Ayrıca, ARDL sınır testi kısıtsız hata modeline dayanmaktadır. Dolayısıyla kısıtsız hata düzeltme modeli (UECM) basit bir lineer dönüşüm yoluyla ARDL sınır testinden türetilebilmekte ve böylece UECM ile uzun dönemde herhangi bir bilgi kaybetmeden kısa dönem dinamiğini uzun dönem dengesiyle birleştirilebilmektedir (Shazbaz, 2012: 18-19).

ARDL sınır testi, değişkenlerin farklı derecede durağan olmaları durumunda uygulanabilmesine rağmen, modelde ikinci dereceden durağan I(2) değişkenlerin varlı̆̆ı, testin sağlam sonuçlar üretmesine engel olabilmektedir (Kıran \& Güriş, 2011: 74). Bu bağlamda, ARDL testinden elde edilen tahminlerin sağlamlığını arttırabilmek amacıyla analizden önce değişkenler için birim kök testleri yapılmıştır.

\subsection{Birim Kök Testi Sonuçları}

Serilerde birim kökün varlığını incelemek için üç farklı birim kök testi kullanılmıştır. Bu testler; Dickey ve Fuller (1979) ile Dickey ve Fuller (1981), Phillips ve Perron (1988) ve Kwiatkowski, Phillips, Schmidt ve Shin (1992) testleridir. ADF (AugmentedDickey-Fuller) ve PP (Phillips-Perron) birim kök testleri, durağan olmayan seriyi sıfir hipotezi olarak ele alırken, KPSS (Kwiatkowski, Phillips, Schmidt ve Shin) testi durağan seriyi sıfır hipotezi olarak ele almaktadır.

ADF birim kök testinde hata terimlerinin istatistiksel olarak bağımsız, homojen ve sabit varyanslı olduğu varsayılmaktadır. Bu metodoloji kullanılırken, hata terimleri arasında korelasyon olmadığına ve sabit varyansa sahip olduklarına emin olmak gerekmektedir. Ancak PP testinde hata terimlerine ilişsin daha esnek varsayımlar benimsenmiştir. Bu testte, ADF birim kök testindeki hata terimlerinin bağımsızlığı ve homojenlik varsayımları terk edilerek, hata terimlerinin zayıf bağımlılı̆̆ ve heterojen dağılımı kabul edilmiştir (Tarı, 2010: 400). PP Testinde olası bir otokorelasyon sorununun hesaplanan t-istatistiği üzerindeki etkileri, Newey-West hata düzeltme mekanizması ile ardışık bağımlılık ortadan kaldırılarak ve böylece eş varyans varsayımı yerine getirilerek çözülmektedir. ADF ve PP birim kök testlerinde, hesaplanan t-istatistiği McKinnon (1996) tablo kritik değerleriyle karşılaştırılarak serinin durağan olup olmadığına karar verilmektedir. H0 hipotezi serinin durağan olmadığını (birim kök içerdiğini), H1 hipotezi ise serinin durağan olduğunu (birim kök içermediğini) ifade etmektedir. Test istatistiği kritik değerden büyük ise H0 reddedilememekte ve seri birim kök içermektedir. Test istatistiği kritik değerden küçük ise $\mathrm{H} 0$ reddedilmekte ve serinin birim kök içermediği yani durağan olduğu kabul edilmektedir.

KPSS birim kök testinde ise, incelenen seri trendden arındırılarak test edilmekte ve temel hipotezin reddedilememesi incelenen serinin durağan olduğunu göstermektedir. Bu testte kullanılan test istatistiği kalıntılara dayanan bir LM testidir (Şentürk \& Akbaş, 2014: 5824). KPSS testinin uygulanmasında Bartlett Kernel fonksiyonunun yaygın olarak kullanıldığı görülmektedir. Elde edilen KPSS test istatistiği literatürde yaygın kullanım şekliyle Kwiatkowski vd. (1992)'nin \%5 anlamlılık düzeyindeki kritik değerleriyle karşılaştırılarak serinin durağan olup olmadığına karar verilmektedir. KPSS testinde kurulan H0 hipotezi serinin durağan olduğunu (birim kök içermediğini), altenatif hipotez (H1) ise serinin durağan olmadığını ifade etmektedir. Test istatistiği kritik değerden büyük ise H0 reddedilmekte ve seri birim kök içermektedir. Test istatistiği kritik değerden küçük ise H0 reddedilememekte ve serinin birim kök içermediği yani durağan olduğu kabul edilmektedir. 
International Journal of Scientific and Technological Research ISSN 2422-8702 (Online), DOI: 10.7176/JSTR/7-01-07

Tablo 3. Birim kök testi sonuçları

\begin{tabular}{|c|c|c|c|c|}
\hline \multicolumn{5}{|c|}{ ADF birim kök testi } \\
\hline \multirow{2}{*}{ Değişken } & \multicolumn{2}{|l|}{ Sabitli } & \multicolumn{2}{|c|}{ Sabitli \&Trendli } \\
\hline & Seviye & Birinci Fark & Seviye & Birinci Fark \\
\hline $\operatorname{lnGini}$ & $-2.609(3)$ & $-2.676(0)^{* * *}$ & $-2.773(3)$ & $-2.586(0)$ \\
\hline $\operatorname{lnFD}$ & $-3.806(5)^{*}$ & - & $-3.121(2)$ & $-4.060(7) * *$ \\
\hline $\begin{array}{l}\operatorname{lnGOVR} \\
\mathrm{N}\end{array}$ & $-2.927(0)^{* * *}$ & - & $-3.157(0)$ & $-5.696(0)^{*}$ \\
\hline $\begin{array}{l}\operatorname{lnMODE} \\
\mathrm{RN}\end{array}$ & $-1.405(0)$ & $-5.817(0)^{*}$ & $-1.724(0)$ & $-6.064(0)^{*}$ \\
\hline $\begin{array}{l}\text { lnHUMA } \\
\text { NCAP }\end{array}$ & $1.129(6)$ & $-3.617(4)^{*}$ & $-2.779(1)$ & $-4.491(4)^{*}$ \\
\hline $\operatorname{lnINF}$ & $-0.658(0)$ & $-5.231(0)^{*}$ & $-2.083(0)$ & $-5.031(0)^{*}$ \\
\hline $\operatorname{lnTL}$ & $-1.760(0)$ & $-4.657(1)^{*}$ & $-3.270(1)^{* * *}$ & - \\
\hline \multirow{3}{*}{$\begin{array}{l}\text { Kritik } \\
\text { Değerler }\end{array}$} & $*:-3.700$ & $*:-3.679$ & $*:-4.339$ & $*:-4.309$ \\
\hline & $* *:-2.976$ & $* *:-2.968$ & $* *:-3.587$ & $* *:-3.574$ \\
\hline & $* * *:-2.627$ & $* * *:-2.622$ & $* * *:-3.229$ & $* * *:-3.222$ \\
\hline \multicolumn{5}{|c|}{ PP birim kök testi } \\
\hline \multirow{2}{*}{ Değişken } & \multicolumn{2}{|l|}{ Sabitli } & \multicolumn{2}{|c|}{ Sabitli \&Trendli } \\
\hline & Seviye & Birinci Fark & Seviye & Birinci Fark \\
\hline $\operatorname{lnGini}$ & $-0.500(4)$ & $-2.623(3)^{* * *}$ & $-2.453(4)$ & $-2.558(3)$ \\
\hline $\operatorname{lnFD}$ & $-1.399(4)$ & $-5.664(0)^{*}$ & $-1.566(1)$ & $-7.082(6)^{*}$ \\
\hline $\begin{array}{l}\operatorname{lnGOVR} \\
\mathrm{N}\end{array}$ & $-3.004(2)^{* *}$ & - & $-3.192(5)$ & $-5.685(1)^{*}$ \\
\hline $\begin{array}{l}\operatorname{lnMODE} \\
\mathrm{RN}\end{array}$ & $-1.497(4)$ & $-5.805(1)^{*}$ & $-1.724(0)$ & $-6.348(5)^{*}$ \\
\hline $\begin{array}{l}\ln H U M A \\
\text { NCAP }\end{array}$ & $1.829(3)$ & $-2.089(2)$ & $-1.247(2)$ & $-2.527(1)$ \\
\hline $\operatorname{lnINF}$ & $-0.685(1)$ & $-5.231(1)^{*}$ & $-2.137(1)$ & $-5.031(1)^{*}$ \\
\hline $\operatorname{lnTL}$ & $-1.473(6)$ & $-5.814(10)^{*}$ & $-2.612(4)$ & $-5.389(5)^{*}$ \\
\hline \multirow{3}{*}{$\begin{array}{l}\text { Kritik } \\
\text { Değerler }\end{array}$} & $*-3.670$ & $*-3.679$ & $*-4.297$ & $*-4.310$ \\
\hline & $* *-2.964$ & $* *-2.968$ & $* *-3.568$ & $* *-3.574$ \\
\hline & $* * *-2.621$ & $* * *-2.623$ & $* * *-3.218$ & $* * *-3.222$ \\
\hline \multicolumn{5}{|c|}{ KPSS birim kök testi } \\
\hline \multirow{2}{*}{ Değişken } & Sabitli & & Sabitli \& Tren & \\
\hline & Seviye & Birinci Fark & Seviye & Birinci Fark \\
\hline $\operatorname{lnGini}$ & $0.490(5)$ & $0.239(4)^{* *}$ & $0.142(4)^{* *}$ & - \\
\hline
\end{tabular}




\begin{tabular}{|lllll|}
\hline $\operatorname{lnFD}$ & $0.638(4)$ & $0.143(1)^{* *}$ & $0.154(4)$ & $0.062(4)^{* *}$ \\
\hline $\begin{array}{l}\operatorname{lnGOVR} \\
\mathrm{N}\end{array}$ & $0.649(4)$ & $0.185(0)^{* *}$ & $0.109(1)^{* *}$ & - \\
\hline $\begin{array}{l}\operatorname{lnMODE} \\
\mathrm{RN}\end{array}$ & $0.662(4)$ & $0.163(1)^{* *}$ & $0.164(4)$ & $0.095(4)^{* *}$ \\
\hline $\begin{array}{l}\text { lnHUMA } \\
\text { NCAP }\end{array}$ & $0.732(4)$ & $0.294(3)^{* *}$ & $0.129(4)^{* *}$ & - \\
\hline $\begin{array}{l}\ln I \mathrm{NF} \\
\text { lnTL }\end{array}$ & $0.590(4)$ & $0.210(0)^{* *}$ & $0.105(4)^{* *}$ & - \\
\hline $\begin{array}{l}\text { Kritik } \\
\text { Değerler }\end{array}$ & $* * 0.463$ & $0.217(13)^{* *}$ & $0.122(2)^{* *}$ & - \\
\hline
\end{tabular}

Not: Tabloda verilen istatistikler serilere ait test istatistikleri olup, parantez içindeki değerler ADF testi için Akaike bilgi kriterine (AIK) göre belirlenmiş optimal gecikme uzunluğunu, PP ve KPSS testleri için Bartlett Kernel kullanılarak Newey-West bant genişliği yöntemine göre belirlenmiş bant genişliklerini göstermektedir. Serilerin durağan olup olmadıklarına karar vermek için serilerin ADF ve PP testleri t-istatistikleri McKinnon (1996) one-sided “p olasılık değerleri” ile karşılaştırılırken, KPSS testinin LM istatistikleri ise Kwiatkowski vd. (1992)'nin \%5 anlamlılık düzeyindeki olasılık değerleri ile karşılaştırılmaktadır. *, **, *** sırasıyla \%1, \%5 ve \%10 anlam düzeyinde durağanlığı ifade etmektedir. Tüm değişkenler logaritmik formlarına dönüştürülerek kullanılmıştır.

Tablo 3'de serilere ait birim kök test sonuçları verilmiştir. ADF testi için sabitli modeled $\ln F D$ ve $\ln G O V R N$ serileri dışındaki tüm seriler birinci farkı alındığında durağan [I(1)] iken, $\ln F D$ ve $\ln G O V R N$ serileri ise seviyede durağandır [I(0)]. ADF testi için sabitli-trendli modelde $\ln T L$ serisi dışındaki tüm seriler I(1) iken, $\ln T L$ serisi I(0)'dır. PP testinin sonuçları incelendiğinde; sabitli modelde yalnızca $\ln G O V R N$ serisinin $\mathrm{I}(0)$ olduğu, $\ln H U M A N C A P$ hariç diğer serilerin I(1) olduğu ve sabitli-trendli modelde ise tüm serilerin I(1) olduğu görülmektedir. InHUMANCAP serisi ise PP testinin sabitli modelinde I(1)'de durağanlaşmamaktadır. Bu seri için ADF ve PP testlerinin sabitli modelinde ulaşılan sonuçların farklı olması, InHUMANCAP serisinin sabitli modelde durağan olup olmadığını kesinleştirebilmek için üçüncü bir birim kök testinin yapılmasını gerektirmektedir.Bu bağlamda yapılan KPSS testinin birim kök sonuçları incelendiğinde, sabitli modelde tüm serilerin I(1) olduğu, sabitlitrendli model için yalnızca $\ln F D$ ve $\operatorname{lnMODERN}$ serilerinin $\mathrm{I}(1)$, diğerlerinin ise $\mathrm{I}(0)$ olduğu anlaşılmaktadır.

Sonuç olarak, yapılan birim kök testleri serilerin durağanlık dereceleri için I(0) ve I(1) arasında karma sonuçlar üretsede, serilerin en çok birinci farkları alındığında durağanlaştığı belirlenmiştir. Böylece uygulanan ARDL sınır testi için, modelde testin sağlam sonuçlar vermesini engelleyecek, ikinci dereceden durağan I(2) serilerin olmadığına karar verilmiştir.

\subsection{ARDL Sinır Testi ve Katsayıların Tahmini}

Eşitlik (1) için ARDL sınır testi ile eş bütünleşmeyi test eden kısıtsıı hata düzeltme modeli (ECM) aşağıdaki gibidir:

$\Delta \ln G I N I_{t}=\gamma_{1}+\gamma_{2} \ln G I N I_{t-1}+\gamma_{3} \ln F D_{t-1}+\gamma_{4} \ln F D^{2}{ }_{t-1}+\sum_{j=5}^{9} \gamma_{j} \ln X_{j t-1}+\sum_{i=1}^{a} \delta_{1 i} \Delta G I N I_{t-i}+$ $\sum_{i=0}^{b} \delta_{2 i} \Delta F D_{t-i}+\sum_{i=0}^{c} \delta_{3 i} \Delta F D_{t-i}^{2}+\sum_{i=0}^{d j} \delta_{2 j i} \Delta X_{j t-i}+u_{t}$

Eşitlik (2)'de $\Delta$, değişkenlerin birinci farkını gösteren fark işlemcisi; a, b, c ve d ilgili değişkenler için optimal gecikme uzunluğunu ve $u_{t}$ hata terimini göstermektedir. ARDL sınır testi yöntemi gecikmeli uzunluğunun (m) seçimine duyarlıdır. Gecikme uzunluğunun uygun olmayan şekilde seçilmesi yanlı sonuçlar verebilmektedir (Shazbaz, 2012). Bu nedenle analize geçmeden önce optimal gecikme uzunluğu AIC, SC ve HQ bilgi kritleri kullanılarak seçilmiştir. Gecikme uzunluğunun belirlenmesi için 
maksimum 3 gecikmeye kadar modeller tahmin edilmiş ve hesaplanan AIC, SC ve HQ bilgi kriterleri incelenerek, uygun gecikme uzunluğu " 1 " olarak belirlenmiştir.

Gecikme uzunluğu belirlendikten sonra değişkenler arasında eş bütünleşmenin olup olmadığını test etmek için Eşitlik (2) tahmin edilmiş ve $\mathrm{F}$ istatistiği hesaplanarak, bu istatistik için belirlenen kritik sınırlarla karşılaştırılmıştır. Peseran, Shin ve Smith (2001) tarafından geliştirilen kritik sınırlar büyük örnekler ( $T=500$ ve $T=40,000$ ) için uygundur ve Narayan ve Narayan (2005) bu kritik değerlerin küçük örneklerde kullanılması durumunda, seriler arasındaki eş bütünleşmeye ilişkin yanlı tahminler oluşabileceğini ileri sürmüştür. $\mathrm{Bu}$ nedenle çalışmamızda $\mathrm{F}$ istatistiğinin değerlendirilmesi için Peseran vd. (2001)'nin kritik sınırları yerine, örnek büyüklügümüze daha uygun olması nedeniyle Narayan (2005) tarafindan küçük örnekler için oluşturulan kritik sınırlar kullanılmıştır.

Eşitlik (2) için değişkenler arasında uzun dönem ilişkinin olmadığı yokluk hipotezi (H0) ve uzun dönem ilişkinin varlığını gösteren alternatif hipotez (H1) aşağıdaki gibidir:

$\mathrm{n}=1, \ldots, 5$ olmak üzere;

$$
\begin{aligned}
& \mathrm{H} 0: \beta_{2}=\beta_{3}=\sum_{j=4}^{n} \beta_{j}=0 \\
& \mathrm{H} 1: \beta_{2} \neq \beta_{3} \neq \sum_{j=4}^{n} \beta_{j} \neq 0
\end{aligned}
$$

Buna göre, F istatistiği üst sınır değerlerinden daha büyükse, değişkenler arasında uzun dönem ilişkisinin olmadığını söyleyen H0 hipotezi reddedilmekte ve H1 hipotezi kabul edilmektedir. F istatistiği alt ve üst kritik değerlerin arasına düşerse, değişkenler arasındaki uzun dönem ilişkileri hakkında kesin bir yorum yapılamamakta ve F istatistiği alt kritik değerden küçük ise H0 hipotezi kabul edilmektedir (Kıran \& Güriş, 2011). Eşitlik (2) için ARDL sınır testi sonuçları (F istatistiği ve kritik sinırlar), seri korelasyon (Breusch-Godfrey Serial Correlation LM Test), normallik (Jarque-Bera), fonksiyonel form (Ramsey RESET Test) ve değişen varyans (Breusch-Pagan-Godfrey) tanı testlerinin sonuçları ile birlikte Tablo 4'de verilmiştir.

Tablo 4. ARDL sınır testi sonuçları

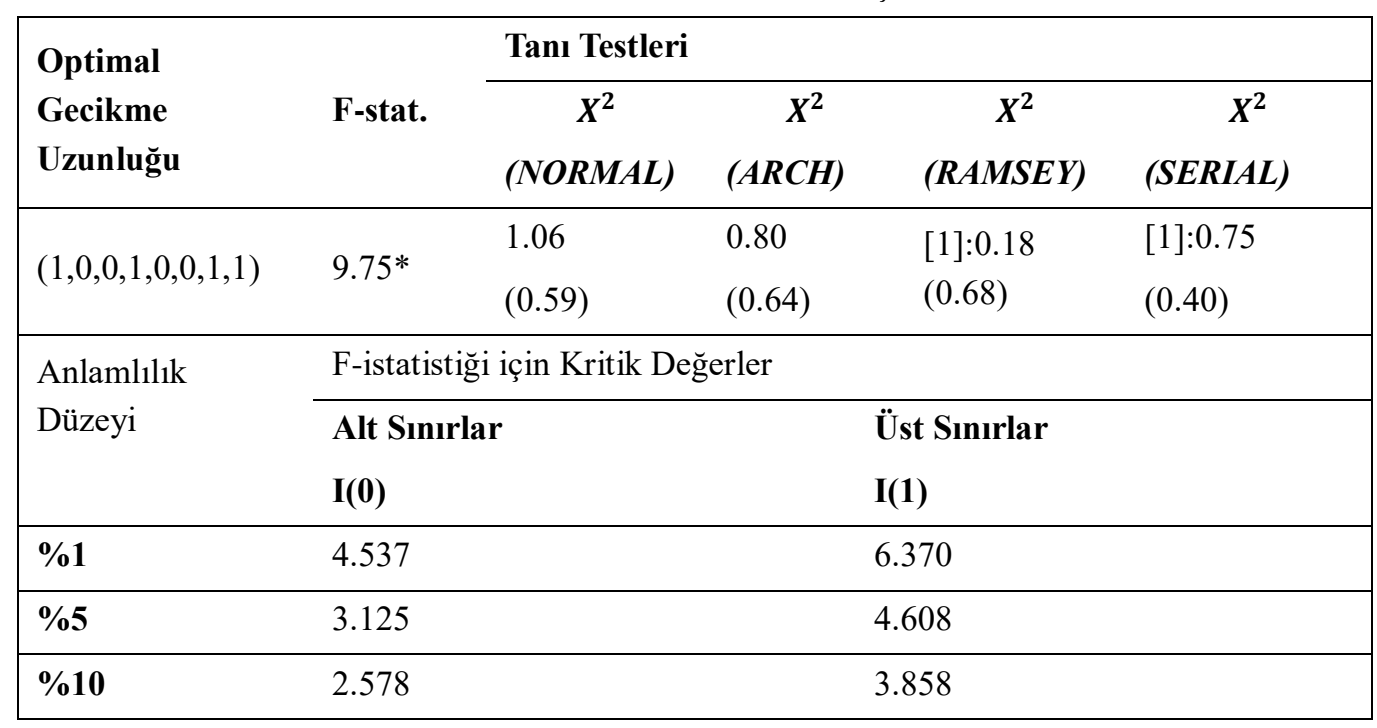

Not: $*, * *, * * *$ sirasıyla $\% 1, \% 5$ ve $\% 10$ düzeylerinde anlamlılı̆̆ 1 göstermektedir. Kritik değerler Narayan (2005)'ın Case III: T=30 ve k=5 için önerdiği kısıtsız sabit ve trendsiz modeldeki değerler olarak belirlenmiştir. Uygun gecikme uzunluğunun seçiminde Schwarz bilgi kriterlerinden (SC) yararlanılmış ve her değişken için maksimum gecikme uzunluğu 1 olarak ayarlanmıştır.

ARDL sınır testinin sonuçları Tablo 4'de gösterilmektedir. Eşitlik (2) için sınır testinden elde edilen F istatistik değerinin \%1 anlamlllık düzeyinde Narayan (2005) tarafindan üretilen üst kritik değerden yüksek olması nedeniyle, değişkenler arasında eş bütünleşme olmadığını ifade eden boş hipotez (H0) reddedilmiş, değişkenler arasında eş bütünleşme olduğunu ifade eden alternatif hipotez (H1) kabul edilmiştir. Aynı zamanda eşitlik (2) için yapılan tüm tanısal testler \%1 anlamlılık düzeyinde, klasik 95 | P a g e 
doğrusal regresyon modeli varsayımlarının herhangi birinin ihlal edilmediğini göstermektedir. ARCH test sonuçları artıkların değişen varyans sorunu taşımadığını desteklemektedir. Ramsey-Reset testi oluşturulan modelin fonksiyonel formunun doğruluğunu onaylamaktadır. Kalıntıların normallik dağı̆lımını incelemek için Jarque-Berra istatistiği kullanılmış ve kalıntıların normal dağılımlı olduğu anlaşılmıştır. Breusch-Godfrey LM testinin sonucu ise kalıntılarda seri korelasyonun varlığını reddetmektedir. Ayrıca, tahmin edilen model için katsayıların kararlılığı CUSUM ve CUSUMSQ kararlılık testleri ile incelenmiştir. Test sonuçları Şekil 1 ve Şekil 2'de verilmiştir.

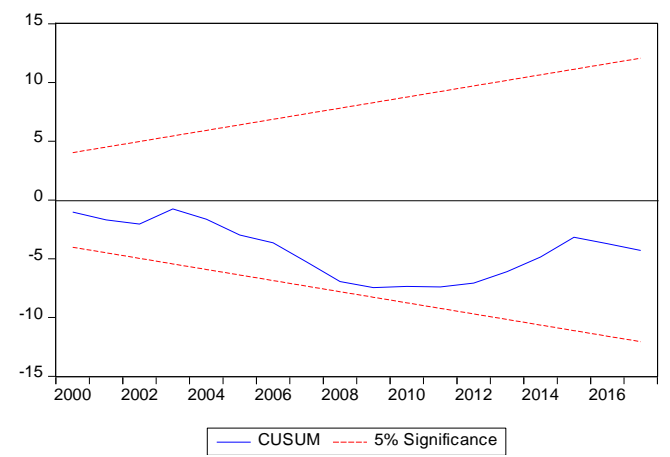

Şekil 1: Özyinelemeli Kalıntıların Kümülatif Toplamı

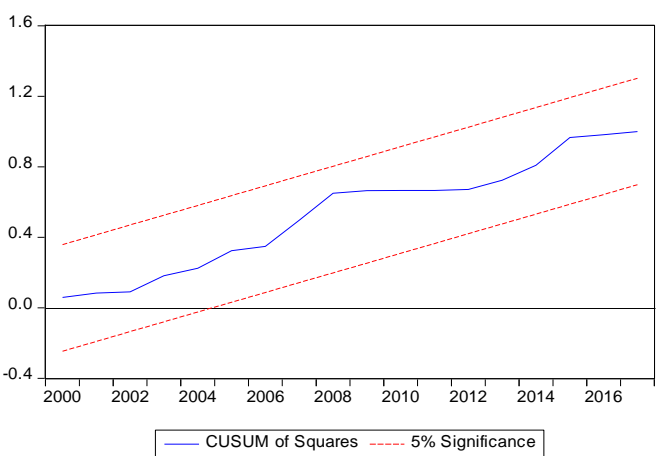

Şekil 2: Özyinelemeli Kalıntıların

Karelerinin Kümülatif Toplamı

Şekil 1 ve 2 incelendiğinde, özyinelemeli kalıntıların kümülatif toplamını (CUSUM) ve özyinelemeli kalıntıların karelerinin kümülatif toplamını (CUSUMQ) gösteren çizimlerin sınırlar içinde (\%95 güven aralığında) olduğu görülmektedir. Bu testler tahminlerin kararlılı̆̆ını doğrulamaktadır.

Değişkenler arasında eş bütünleşmenin bulunmasının ardından, ARDL yöntemi kullanılarak finansal gelişme, finansal gelişmenin karesi, kamu nihai tüketim harcamaları, modern sektör, beşeri sermaye, enflasyon ve ticari açıklığın uzun dönemde gelir eşitsizliği üzerindeki etkileri incelemek için oluşturulan eşitlik (5) ve eşitlik (6)'daki modeller tahmin edilmiştir:

$$
\begin{aligned}
& \operatorname{lnGINI}_{t}=a_{1}+\sum_{i=1}^{m} a_{1 i} \operatorname{GINI}_{t-i}+\sum_{i=0}^{n} a_{2 i} F D_{t-i}+\sum_{i=0}^{p} a_{3 i} F D^{2}{ }_{t-i}+\sum_{i=0}^{r} a_{4 j i} X_{j t-i}+u_{t} \\
& \begin{array}{l}
\Delta \operatorname{lnGINI}_{t}=\theta_{1}+\sum_{i=1}^{m} \theta_{1 i} \Delta G I N I_{t-i}+\sum_{i=0}^{n} \theta_{2 i} \Delta F D_{t-i}+\sum_{i=0}^{p} \theta_{3 i} \Delta F D^{2}{ }_{t-i}+\sum_{i=0}^{r} \theta_{4 j i} \Delta X_{j t-i}+ \\
\varphi E C T_{t-1}+u_{t}
\end{array}
\end{aligned}
$$

Değişkenlere ilişkin uzun dönemli katsayı tahminleri Tablo 5'de verilmiştir. Sonuçlar incelendiğinde, beşeri sermaye değişkeninin katsayısı dışında diğer değişkenler için tahmin edilen tüm katsayıların beklenen işarette ve istatistiki olarak anlamlı olduğu görülmektedir. Analizden elde edilen bulgulara gore modeldeki temel açıklayıcı değişken olan finansal gelişmeye ait katsayı pozitif ve istatistiki olarak anlamlı iken finansal gelişmenin karesine ait katsayı ise negatif ve istatistiki olarak anlamlıdır.

Finansal gelişmeye ilişkin bu katsayılar Türkiye'de finansal gelişme ve gelir eşitsizliği arasındaki ilişkinin Greenwood ve Jovanovic (1990)'in ileri sürdüğü gibi ters-U şeklinde olduğunu ve finansal gelişmenin belirli bir eşik düzeyden sonra gelir eşitsizliğini azalttığını göstermektedir. Buna göre finansal gelişmedeki \%1'lik bir artış uzun dönemde gelir eşitsizliğini belirli bir eşik düzeye kadar \% 0.78 arttırırken, bu eşik düzeyden sonra finansal gelişmede meydana gelecek her $\% 1$ 'lik artış gelir eşitsizliğini \%0.11 azaltmaktadır. Bu bulgular, Türkiye için finansal gelişme ve gelir eşitsizliğ̣i ilişkisini inceleyen Akıncı ve Akıncı (2016), Destek vd. (2017), Koçak ve Uzay (2019) ile Destek vd. (2020)'nin çalışmaları ile tutarlı iken, Türkiye için finansal gelişme ve gelir eşitsizliği arasında negatif ve doğrusal bir iliş̧i olduğu sonucuna ulaşan Kanberoğlu ve Arvas (2014), Altunöz (2015), Çetin ve Şeker (2017) ile Altıntaş ve Çalışır (2018)'ın çalışmalarıyla çelişmektedir.

Modele kontrol değişkeni olarak dahil edilen kamu nihai tüketim harcamalarına ait katsayılar incelendiğinde, kamu nihai tüketim harcamalarının GSYIH içerisindeki payında meydana gelen \%1'lik bir artışın uzun dönemde gelir eşitsizliğini $\% 0.08$ azalttığı görülmektedir. Kamu nihai tüketim harcamaları için elde edilen bu sonuç beklentilerimizle tutarlıdır. Aynı şekilde, modern sektörün 
katsayısının da beklentilerimiz doğrultusunda negatif ve istatistiksel olarak anlamlı olduğu görülmektedir. Buna göre, modern sektörün GSYIH'daki payında meydana gelen \% $\%$ 'lik bir artış, uzun dönemde gelir eşitsizliğini \%0.91 azaltmaktadır. Modern sektör için ulaşılan bu sonuç, Kuznets (1955)'in gelir eşitsizliğinin ekonomideki sektör yapısına bağlı olabileceğini görüşünü desteklemektedir.

Enflasyonun gelir eşitsizliği üzerindeki etkisi incelendiğinde, enflasyon oranındaki \%1'lik bir artışın uzun dönemde gelir eşitsizliğini \%0.02 oranında arttırdığı görülmektedir. Enflasyonun gelir eșitsizliği üzerindeki etkisini gösteren katsayının pozitif olması Romer ve Romer (1998)'in ileri sürdüğü gibi enflasyon oranındaki artışın gelir eşitsizliğini arttırarak yoksullara zarar verdiği görüş̧ünü desteklemesine rağmen, bu etkinin düşük düzeyde olduğu görülmektedir. Aynı şekilde ticari açıklığın gelir eşitsizliği üzerindeki etkisini gösteren katsayı da beklentilerimizle uyumlu şekilde negatif ve anlamlı olmasına rağmen, ticari açıklığın uzun dönemde gelir eşitsizliği üzerindeki etkisi de düşük düzeydedir. Buna göre, ticari açıklıktaki \%1'lik bir artış uzun dönemde gelir eşitsizliğini \%0.06 azaltmaktadır.

Son olarak Türkiye'de beşeri sermayenin gelir eşitsizliği üzerindeki uzun dönemli etkisini gösteren katsayı incelendiğinde ise, katsayının beklentilerimizin dışında pozitif ve istatistiksel olarak anlamlı olduğu görülmektedir. Beşeri sermayede meydana gelen \%1'lik bir artış, uzun dönemde gelir eşitsizliğini $\% 0.51$ arttırmaktadır. Elde edilen bu bulgu, eğitimdeki artışın vasıflı işgücünü arttıracağ 1 ve vasıfll/vasıfsız işçi ücretlerindeki farkların azalarak gelir eşitsizliğinde bir azalmaya yol açacağını ileri süren Batuo vd. (2010) ile Kar ve Kar (2019)'ın sonuçlarıyla çelişmektedir. Ancak Türkiye'de 2018 yılı itibariyle ileri eğitimli işgücünün yaklaşık \%80'i istihdam edilirken, ortaöğretimli iş gücünün yaklaşık \%60'1 ve temel eğitimli iş gücünün ise yaklaşık $\% 52$ 'si iş bulabilmektedir. Bu durum, toplam iş gücüne katılım oranının 2018 yılı itibariyle yaklaşık \%58 olduğu Türkiye'de, beşeri sermayeye yatırım yapmış nitelikli işgücü ile niteliksiz iş gücü arasındaki gelir farklılıklarının artmasına yol açmaktadır (WDI, 2020).

Tablo 5. ARDL uzun ve kısa dönem tahmin sonuçları

\begin{tabular}{|c|c|c|c|c|}
\hline \multicolumn{5}{|c|}{$\begin{array}{l}\text { ARDL Uzun Dönem Tahmin Sonuçları } \\
(\mathbf{1 , 0 , 0 , 1 , 0 , 0 , 1 , 1 )}\end{array}$} \\
\hline \multirow{2}{*}{$\begin{array}{l}\text { Bağımsız } \\
\text { Değişkenler }\end{array}$} & \multicolumn{4}{|c|}{ Bağımlı Değişken: InGini } \\
\hline & Katsayı & Standat Hata & T-istatistikleri & $\begin{array}{l}\text { Olasılık } \\
\text { Değerleri }\end{array}$ \\
\hline $\ln F D$ & $0.78^{* *}$ & 0.30 & 2.58 & 0.02 \\
\hline $\ln F D^{2}$ & $-0.11 * *$ & 0.05 & -2.53 & 0.02 \\
\hline $\operatorname{lnGOVERN}$ & $-0.08 * *$ & 0.04 & -2.20 & 0.04 \\
\hline $\operatorname{lnMODERN}$ & $-0.91 * * *$ & 0.47 & -1.95 & 0.07 \\
\hline $\operatorname{lnHUMANCAP}$ & $0.51 * * *$ & 0.28 & 1.83 & 0.08 \\
\hline $\ln I N F$ & $0.02 * *$ & 0.01 & 2.30 & 0.03 \\
\hline $\ln T R A D E O P$ & $-0.06 * *$ & 0.03 & -1.97 & 0.06 \\
\hline \multicolumn{5}{|c|}{ ARDL Hata Düzeltme Modeli Sonuçları } \\
\hline \multirow{2}{*}{$\begin{array}{l}\text { Bağımsız } \\
\text { Değişkenler }\end{array}$} & \multicolumn{4}{|c|}{ Bağımlı Değişken: $\Delta$ lnGini } \\
\hline & Katsayı & Standat Hata & T-istatiskleri & $\begin{array}{l}\text { Olasılık } \\
\text { Değerleri }\end{array}$ \\
\hline $\mathrm{C}$ & $1.25^{*}$ & 0.12 & 10.40 & 0.00 \\
\hline$\triangle \ln G O V E R N$ & $-0.01 * *$ & 0.00 & -2.21 & 0.04 \\
\hline
\end{tabular}




\begin{tabular}{|c|c|c|c|c|}
\hline$\Delta \ln I N F$ & 7.15 & 0.00 & 0.10 & 0.92 \\
\hline$\triangle \ln T R A D E O P$ & $-0.01 *$ & 0.00 & -2.90 & 0.01 \\
\hline$E C T_{t-1}$ & $-0.19 *$ & 0.02 & -10.41 & 0.00 \\
\hline$R^{2}$ & 0.83 & & & \\
\hline Adjusted $R^{2}$ & 0.81 & & & \\
\hline F-stat. & $30.93(0.00)$ & & & \\
\hline \multirow{3}{*}{$\begin{array}{l}\text { Anlamlılık } \\
\text { Düzeyi }\end{array}$} & \multicolumn{4}{|c|}{ t-istatistiği için Kritik Değerler } \\
\hline & Alt Sinurlar & & Üst Sınırlar & \\
\hline & $\mathbf{I}(\mathbf{0})$ & & $\mathbf{I}(\mathbf{1})$ & \\
\hline$\% 1$ & -3.43 & & -5.19 & \\
\hline$\% 5$ & -2.86 & & -4.57 & \\
\hline$\% 10$ & -2.57 & & -4.23 & \\
\hline
\end{tabular}

Not: *, **, *** srasıyla $\% 1, \% 5$ ve $\% 10$ düzeylerinde anlamlılı̆̆ göstermektedir.Katsayılar kısıtsız sabit ve trensiz model için yapılan tahminlerden elde edilmiştir. Uygun gecikme uzunluğunun seçiminde Schwarz bilgi kriterlerinden (SC) yararlanılmış ve her değişken için maksimum gecikme uzunluğu 1 olarak ayarlanmıştır.

Değişkenlere ilişkin kısa dönemli katsayı tahminleri Tablo 5' in alt panelinde verilmiştir. Hata teriminin bir dönem gecikmeli değerinin $\left(E C T_{t-1}\right)$ negatif işaretli ve istatistiksel olarak anlamlı olması, değişkenler arasındaki uzun dönemli ilişkinin istikrarına ilişkin kanıtlar sunmaktadır (Keho, 2017: 8). Bu katsayının anlamlı olabilmesi, bu katsayıya ait t-istatistiğinin (-10.41) mutlak değerinin Tablo 4'de t-istatistiği için verilen kritik değerlerin üzerinde olmasına bağlıdır. Tablo 5'de kısa dönem katsayı tahminlerine ilişkin sonuçlar incelendiğinde $E C T_{t-1}$ katsayısının değerinin -0.19 olduğu görülmektedir. Bu katsayı, Türkiye'de meydana gelen ekonomik bir şoktan sonra, uzun dönem dengesinde meydana gelen bir sapmanın ya da dengesizliğin bir yıl içerisinde yaklaşık \%19'unun düzelerek uzun dönemli dengeye yaklaşacağını göstermektedir. Değişkenlerin kısa dönemde gelir eşitsizliği üzerindeki etkisini incelemek için tahmin edilen katsayılar incelendiğinde ise, kısa dönemde yalnızca kamu nihai tüketim harcamalarının ve ticari açıklığın gelir eşitsizliği üzerinde düşük düzeyli ve istatistiksel olarak anlamlı etkilerinin olduğu anlaşılmaktadır. Buna göre, kamu nihai tüketim harcamalarının GSYIH'daki payında ve ticari açıklıkta meydana gelen $\% 1^{\prime}$ lik bir artış, kısa dönemde gelir eşitsizliğini \%0.01 azaltmaktadır.

\section{Sonuç}

Finansal gelişme bir ülkenin ekonomik büyümesini belirleyen önemli bir faktör olarak görülmektedir. Çünkü finans, sermayeyi biriktirme ve toplama sürecinde kaynakları etkin bir şekilde tahsis ederek, ülke ekonomisinin güçlenmesinde önemli bir rol oynamaktadır. Finansal gelişme ekonomik büyümenin yanı sıra, gelirin nasıl dağılacağıyla da yakından ilgilidir. Politika yapıcılar açısından önem taşıyan ve toplumun her kesimini yakından ilgilendiren finansal gelişme ve gelir dağılımı arasındaki ilişki konusunda literatürde çok sayıda çalışma bulunmasına rağmen, bu ilişkinin yönü ve yapısına ilişkin bir fikir birliğine ulaşılamamıştır.

Bu çalışmada Türkiye'de 1987-2017 döneminde finansal gelişme ve gelir eşitsizliği arasındaki uzun dönemli ilişkinin Finansal Kuznets Eğrisi Hipotezi test edilerek incelenmesi amaçlanmıştır. Bu amaçla ARDL sınır testi yaklaşımı kullanılarak, genel finansal gelişme endeksi ile Gini katsayısı arasında bir eş bütünleşme olup olmadığı araştırılmıştır. Çalışmada finansal gelişme ve gelir eşitsizliği arasındaki ilişki incelenirken, ihmal edilmiş değişken sapmasına yol açmamak için, modele literatürde gelir eşitsizliğinin belirleyicisi olarak sıklıkla kullanılan kamu nihai tüketim harcamaları, modern sektör payı, enflasyon oranı, beşeri sermaye ve ticari açıklık değiş̧kenleri de eklenmiştir. Değişkenler arasında uzun dönemli bir eş bütünleşme bulunmasının ardından, ARDL yöntemi kullanılarak uzun ve kısa dönemli katsayı tahminleri yapılmıştır. Ampirik analizlerde finansal gelişmeyi temsil eden katsayı pozitif ve istatistiksel olarak anlamlı, Finansal Kuznets Eğrisi Hipotezini test etmek için modele 98| P a g e 
eklenen finansal gelişmenin karesine ait katsayı ise negatif ve istatistiksel olarak anlamlı bulunmuştur. Böylece, Türkiye'de finansal gelişme ve gelir eşitsizliği arasında Greenwood ve Jovanovic (1990)'in ileri sürdüğü gibi ters-U şeklinde bir ilişki olduğu sonucuna varılmıştır.

Diğer değişkenler için elde edilen uzun dönemli katsayı tahminleri incelendiğinde ise, kamu nihai tüketim harcamaları ve modern sektörün GSYİH içindeki payı arttıkça, gelir eşitsizliğinin azaldığı görülmüştür. Benzer şekilde, ticari açıklık değişkeni için elde edilen katsayı da negatif işaretli ve istatistiksel olarak anlamlı bulunmuş, böylece diş ticaretin GSYİH içindeki payında meydana gelen bir artışın gelir eşitsizliğini azalttığı sonucuna varılmıştır. Enflasyon oranı ve beşeri sermaye değişkenleri için elde edilen pozitif ve istatistiksel açıdan anlamlı uzun dönem katsayılar ise, Türkiye'de enflasyon oranındaki ve beşeri sermayedeki artışların uzun dönemde gelir eşitsizliğini arttırdığına ve yoksullara zarar verdiğine işaret etmektedir.

Türkiye'de finansal gelişmenin belirli bir düzeye ulaşmasının ardından gelir dağılımı eşitsizliğini azalttığına ilişkin olarak ulaşılan sonuçlar, politika yapıcılar için önem taşımaktadır. Türkiye'de düşük ve orta gelir grubunun finansal piyasalara erişimini arttıracak düzenlemeler yapmak, bu gelir gruplarının eğitimleri ve yüksek getirili projeleri için ihtiyaç duyacakları fona daha kolay ulaşmalarını sağlayacaktır. Ancak beşeri sermaye, modern sektör payı ve kamu harcamalarının gelir eşitsizliği üzerindeki etkilerine ilişkin olarak ulaşılan sonuçlar, Türkiye'de gelir eşitsizliğinin azaltılabilmesi için genel olarak niteliksiz iş gücünün istihdam edildiği tarım sektörü ile nitelikli iş gücünün istihdam edildiği modern sektör arasındaki ücret farklılığının, tarım dışı sektörün sübvanse edilerek azaltılması gerektiğini de göstermektedir. Her ne kadar modern sektörün GSYİH içerisindeki payının artması gelir eşitsizliğini azaltsa da, tarımda dışa bağımlılığın azaltılmasının kalkınma sürecinde taşıdığı önem gözardı edilemeyecek kadar büyüktür. Bu bağlamda tarımın GSYİH içerisindeki payının azaltılmasına yönelik politikalar yerine tarım sektörünün modernizasyonunu sağlayacak ve tarım ile modern sektör arasında köprü oluşturacak politikalar izlenmesi istikrarlı bir büyüme ve adil bir bölüşüm için önemli adımlar olacaktır.

\section{Kaynakça}

Ahsan, Z. F., \& Masih, M. (2016). Exploring the nexus between income inequality and financial indicators: Endemic to the İndian Economy? Munich Personal RePEc Archive, No: 69770.

Akıncı, G. Y., \& Akınc1, M. (2016). Ters-u hipotezi bağlamında ekonomik büyüme, finansal kalkınma ve gelir eşitsizliği mekanizmaları üzerine. Finans Politik \& Ekonomik Yorumlar, 53(622), 61-77.

Altıntaş, N., \& Çalışır, M. (2018). Finansal gelişmenin bankacılık ve sermaye piyasası bağlamında gelir dağılımına etkisi: ARDL sınır testi yaklaşımı. Trakya Üniversitesi İktisadi ve İdari Bilimler Fakültesi Dergisi, 7(1), 81-97.

Altunbaş, Y., \& Thornton, J. (2019). Finance and income inequality revisited. Finance Research Letters, 1-9.

Altunöz, U. (2015). Kuznet eğrisi bağlamında türkiye'de finansal gelişme ve gelir eşitsizliği ilişkisinin analizi. International Conference on Eurasian Economies.SESSION 6E: Kalkınma I, s. 871-875. Kazan, Russia: Eurasian Economists Association.

Argun, A. İ. (2016). Gelişmekte olan ülkelerde finansal gelişme ve gelir eşizsizliği. İstanbul Üniversitesi Sosyal Bilimler Dergisi (1), 61-74.

Azam, M., \& Raza, S. A. (2018). Financial sector development and income inequality in ASEAN-5 countries: Does financial Kuznets curve exists? Global Business and Economics Review, 20(1), 88-114.

Bae, K. B., Han, D., \& Sohn, H. (2012). İmportance of access to finance in reducing income inequality and poverty level. International Review of Public Administration, 17(1), 55-77. 
Bahmani-Oskooee, M., \& Zhang, R. (2015). On the impact of financial development on income distribution: Time-series evidence. Journal Applied Economics, 47(12), 1248-1271.

Banerjee, A. V., \& Newman, A. F. (1993). Occupational choice and process of development. Journal of Political Economy, 101(2), 274-298.

Batuo, M. E., Guidi, F., \& Mlambo, K. (2010). Financial development and income inequality: Evidence from African countries. Munich Personal RePEc Archive, No: 2658, 1-27.

Beck, T., Demirgüç-Kunt, A., \& Levine, R. (2007). Finance, inequality and the poor. Journal of Economic Growth, 12, 27-49.

Belen, M., \& Karamelikli, H. (2016). Finansal gelişme ve yoksulluğun azalması arasındaki ilişki: Ampirik bir inceleme. Abant İzet Baysal Üniversitesi Sosyal Bilimler Enstitüsü Dergisi, 16(1), $125-141$

Clarke, G. R., Xu, L. C., \& Zou, H.-f. (2006). Finance and income inequality: What do the data tell us? Southern Economic Journal, 72(3), 578-596.

Clarke, G., Xu, L. C., \& Zou, H.-f. (2003). Finance and income inequality: Test of alternative theories. Policy Research Working Paper, No: 2984.

Çetin, M., \& Şeker, F. (2017). Finansal gelişmenin gelir eşitsizliği üzerindeki etkisi: Türkiye ekonomisi için ampirik bir kanıt. International Anatolia Academic Online Journal/Social Science Journal, 3(2), 52-63.

De Haan, J., \& Sturm, J.-E. (2017). Finance and income inequality: A review and new evidence. European Journal of Political Economy, 50, 171-195.

Demirgüç-Kunt, A., \& Levine, R. (2008). Finance and economic opportunity. Policy Research Working Paper, No:4468 .

Destek, M. A., Okumuş, İ., \& Manga, M. (2017). Türkiye'de finansal gelişim ve gelir dağılımı ilişskisi: Finansal Kuznets eğrisi. Doğuş Üniversitesi Dergisi, 18(2), 153-165.

Destek, M. A., Sinha, A., \& Sarkodie, S. A. (2020). The relationship between financial development and income inequality in Turkey. Journal of Economic Structures, 9(11), 1-14.

Dickey, D. A., \& Fuller, W. A. (1979). Distribution of the estimators for autoregressive time series with a unit root. Journal of American Statistical Association, 74(366a), 427-431.

Dickey, D. A., \& Fuller, W. A. (1981). Likelihood ratio statistics for autoregressive time series. Econometrica, 49(4), 1057-1072.

Galor, O., \& Zeira, J. 1. (1993). Income Distrubution and Macroeconomics. Review of Economic Studies, 60 (1), 35-52.

Greenwood, J., \& Jovanovic, B. (1990). Financial development, growth and the distribution of income. Journal of Political Economy, 98(5), 1076-1107.

Guru, B. K., \& Yadav, I. S. (2019). Financial development and economic growth: Panel evidence from BRICS. Journal of Economics, Finance and Administrative Science, 24(47), 113-126. 
IMF (International Monetary Fund), Erişim: https://www.imf.org/external/pubs /ft/weo /2020/01/weodata/weorept.aspx $?$ sy $=1980 \&$ ey $=2019 \&$ scsm $=1 \&$ ssd $=1 \&$ sort $=$ country \&ds $=\% 2 \mathrm{C}$ $\& \mathrm{br}=1 \& \mathrm{pr} 1 . \mathrm{x}=49 \& \mathrm{pr} 1 . \mathrm{y}=2 \& \mathrm{c}=186 \& \mathrm{~s}=\mathrm{NGDP}$ RPCH\%2CNGDPRPPPPCPCH\%2CPCPIPCH \%2CPCPIEPCH\%2CLUR\&grp=0\&a= (2020, Nisan 27).

Kanberoğlu, Z., \& Arvas, M. A. (2014). Finansal kalkınma ve gelir eşitsizliği: Türkiye örneği, 1980-2012. Sosyoekonomi (1), 106-122.

Kar, B. B., \& Kar, M. (2019). Finansal gelişme ve gelir eşitsizliği: BRICS ekonomileri için dinamik heterojen bir yaklaşım. Anadolu Üniversitesi Sosyal Bilimler Dergisi, 19(1), 27-46.

Keho, Y. (2017). The impact of trade openness on economic growth: The case of Cote d'Ivoire. Cogent Economics \& Finance, 5(1), 1-14.

King, R. L., \& Levine, R. (1993). Finance, entrepreneurship and growth: Theory and evidence. Journal of Monetary Economics, 32, 513-542.

Kıran, B., \& Güriş, B. (2011). Türkiye'de ticari ve finansal açıklığın büyümeye etkisi. Anadolu Üniversitesi Sosyal Bilimler Dergisi, 11(2), 69-80.

Koçak, E., \& Uzay, N. (2019). The effect of financial development on income inequality in Turkey: An estimate of the Greenwood-Jovanovic hypothesis. Review of Economic Perspectives, 19(4), 319-344.

Kuznets, S. (1955). Economic growth and income inequality. American Economic Review, 45, 1-28.

Kwiatkowski, D., Phillips, P. C., Schmidt, P., \& Shin, Y. (1992). Testing the null hypothesis of stationarity. Journal of Econometrics, 54(1-3), 159-178.

Law, S. H., \& Tan, H. B. (2009). The role of financial development on income inequality in Malaysia. Journal of Economic Development, 34(2), 153-168.

Levine, R. (2004). Finance and growth: Theory and evidence. Nber Workıng Paper Serles, No: 10766.

Levine, R. (1997). Financial development and economic growth: Views and agenda. Journal of Economic Literature, 3 (2), 688-726.

Levine, R. (2003). More on finance and growth: More finance more growth? Federal Reserve Bank of St. Lous Review, 85, 31-46.

Levine, R., Loayza, N., \& Beck, T. (2000). Financial intermediation and growth: Casuality and causes. Journal of Monetary Economics, 46(1), 1-24.

Lundberg, M., \& Squire, L. (2003). The simultaneous evolution of growth and inequality. The Economic Journal, 113(487), 326-344.

McKinnon, J. G. (1996). Numerical distribution functions for unit root and cointegration tests. Journal of Applied Econometrics, 11(6), 601-618.

McKinnon, R. I. (1973). Money and capital in economic development. The Brookings Institution.

Narayan, P. K. (2005). The saving and investment nexus for China: Evidence from cointegration tests. Applied Economics, 37(17), 1979-1990. 
Narayan, P. K., \& Narayan, S. (2005). Estimating income and price elasticities of imports. Economic Modelling, 22(3), 423-438.

Özdemir, O. (2019). Rethinking the financial Kuznets curve in the framework of income inequality: Empirical evidence on advanced and developing economies. Economics and Business Letters, 8(4), 176-190.

Peseran, M. H., Shin, Y., \& Smith, R. J. (2001). Bounds testing approaches to the analysis of level relationships. Journal of Applied Econometrics, 16(3), 289-326.

Phillips, P. C., \& Perron, P. (1988). Testing for a unit root in time series regression. Biometrica, 75(2), 335-346.

PWT (Penn World Table), Erişim: https:/febpwt.webhosting.rug.nl/Dmn /AggregateXs/ VariableCodeSelecthttps://febpwt.webhosting.rug.n1/Dmn/AggregateXs/VariableCodeSelecthttp s://febpwt.webhosting.rug.nl/Dmn/AggregateXs/VariableCodeSelect (2020, Mayıs 28).

Romer, C. D., \& Romer, D. H. (1998, Kasım). Monetary policy and the well-beingof the poor. NBER Working Paper, No: 6793.

Sehrawat, M., \& Giri, A. K. (2015). Financial development and income inequality in İndia: An application of ARDL approach. International Journal of Social Economics, 42(1), 64-81.

Shaw, E. S. (1973). Financial deepening in economic development. New York, NY: Oxford University Press.

Shazbaz, M. (2012). Does trade openness affect long run growth? Cointegration, causality and forecast error variance decomposition tests for Pakistan. Economic Modelling, 29(6), 23252339.

Solt, F. (2020). Measuring income inequality across countries and over time: The standardized world income inequality database. Social Science Quarterly, 101(3), 1183-1199.

Svirydzenka, K. (2016). Introducing a new broad-based index of financial development. International Monetary Fund Working Paper, No: 16/5.

Şahin, D. (2018). Gelişmiş ülkelerde finansal gelişme ve gelir eşitsizliği ilişkisi. Iğdır Üniversitesi Sosyal Bilimler Dergisi (15), 299-322.

Şentürk, M., \& Akbaş, Y. E. (2014). İşsizlik-enflasyon ve ekonomik büyüme arasındaki karşılıklı ilişkinin değerlendirilmesi: Türkiye örneği. Journal of Yasar University, 9(34), 5820-5832.

Tarı, R. (2010). Ekonometri. Kocaeli: Umuttepe Yayınları.

Thornton, J., \& Di Tommaso, C. (2020). The long-run relationship between finance and income inequality: Evidence from panel data. Finance Research Letters, 32, 1-6.

Topuz, S. G., \& Dağdemir, Ö. (2016). Finansal gelişme ve gelir eşitsizliği: Bir panel veri analizi. Anadolu Üniversitesi Sosyal Bilimler Dergisi, 16(3), 19-34.

WDI (World Development Indicators.), The World Bank. Erişim: https://databank. worldbank. org/source/world-development-indicators (2020, May1s 26). 